\title{
The Tropical Forest and Fire Emissions Experiment: overview and airborne fire emission factor measurements
}

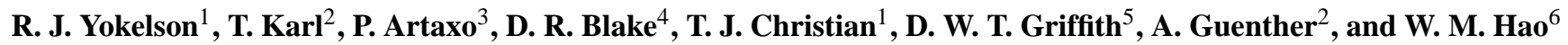 \\ ${ }^{1}$ University of Montana, Department of Chemistry, Missoula, MT, 59812, USA \\ ${ }^{2}$ National Center for Atmospheric Research, Boulder, CO, USA \\ ${ }^{3}$ University of São Paulo, Department of Physics, São Paulo, Brazil \\ ${ }^{4}$ University of California at Irvine, Department of Chemistry, USA \\ ${ }^{5}$ University of Wollongong, Department of Chemistry, Wollongong, New South Wales, Australia \\ ${ }^{6}$ USDA Forest Service, Fire Sciences Laboratory, Missoula, MT, USA
}

Received: 4 May 2007 - Published in Atmos. Chem. Phys. Discuss.: 23 May 2007

Revised: 20 September 2007 - Accepted: 22 September 2007 - Published: 9 October 2007

\begin{abstract}
The Tropical Forest and Fire Emissions Experiment (TROFFEE) used laboratory measurements followed by airborne and ground based field campaigns during the 2004 Amazon dry season to quantify the emissions from pristine tropical forest and several plantations as well as the emissions, fuel consumption, and fire ecology of tropical deforestation fires. The airborne campaign used an Embraer 110B aircraft outfitted with whole air sampling in canisters, mass-calibrated nephelometry, ozone by UV absorbance, Fourier transform infrared spectroscopy (FTIR), and proton-transfer mass spectrometry (PTR-MS) to measure $\mathrm{PM}_{10}, \mathrm{O}_{3}, \mathrm{CO}_{2}, \mathrm{CO}, \mathrm{NO}, \mathrm{NO}_{2}, \mathrm{HONO}, \mathrm{HCN}, \mathrm{NH}_{3}$, OCS, DMS, $\mathrm{CH}_{4}$, and up to 48 non-methane organic compounds (NMOC). The Brazilian smoke/haze layers extended to $2-3 \mathrm{~km}$ altitude, which is much lower than the $5-6 \mathrm{~km}$ observed at the same latitude, time of year, and local time in Africa in 2000. Emission factors (EF) were computed for the 19 tropical deforestation fires sampled and they largely compare well to previous work. However, the TROFFEE $\mathrm{EF}$ are mostly based on a much larger number of samples than previously available and they also include results for significant emissions not previously reported such as: nitrous acid, acrylonitrile, pyrrole, methylvinylketone, methacrolein, crotonaldehyde, methylethylketone, methylpropanal, "acetol plus methylacetate," furaldehydes, dimethylsulfide, and $\mathrm{C}_{1}$ $\mathrm{C}_{4}$ alkyl nitrates. Thus, we recommend these $\mathrm{EF}$ for all tropical deforestation fires. The NMOC emissions were $\sim 80 \%$ reactive, oxygenated volatile organic compounds (OVOC).
\end{abstract}

Correspondence to: R. J. Yokelson

(bob.yokelson@umontana.edu)
Our EF for $\mathrm{PM}_{10}(17.8 \pm 4 \mathrm{~g} / \mathrm{kg})$ is $\sim 25 \%$ higher than previously reported for tropical forest fires and may reflect a trend towards, and sampling of, larger fires than in earlier studies. A large fraction of the total burning for 2004 likely occurred during a two-week period of very low humidity. The combined output of these fires created a massive "mega-plume" $>500 \mathrm{~km}$ across that we sampled on 8 September. The megaplume contained high $\mathrm{PM}_{10}$ and $10-50$ ppbv of many reactive species such as $\mathrm{O}_{3}, \mathrm{NH}_{3}, \mathrm{NO}_{2}, \mathrm{CH}_{3} \mathrm{OH}$, and organic acids. This is an intense and globally important chemical processing environment that is still poorly understood. The mega-plume or "white ocean" of smoke covered a large area in Brazil, Bolivia, and Paraguay for about one month. The smoke was transported $>2000 \mathrm{~km}$ to the southeast while remaining concentrated enough to cause a 3-4-fold increase in aerosol loading in the São Paulo area for several days.

\section{Introduction}

Biomass burning and biogenic emissions are the two largest sources of volatile organic compounds (VOC) and fine particulate carbon in the global troposphere. Tropical forests produce about one-third of the global biogenic emissions and tropical deforestation fires account for much of the global biomass burning (Andreae and Merlet, 2001; Kreidenweis et al., 1999; Guenther et al., 1995, 2006). Recent estimates of the total amount of biomass burned globally vary from about 5 to 7 Pg C/y (Andreae and Merlet, 2001; Page et al., 2002). The contribution of tropical deforestation fires to total global biomass burning has been estimated as 52\% (Crutzen and

Published by Copernicus Publications on behalf of the European Geosciences Union. 

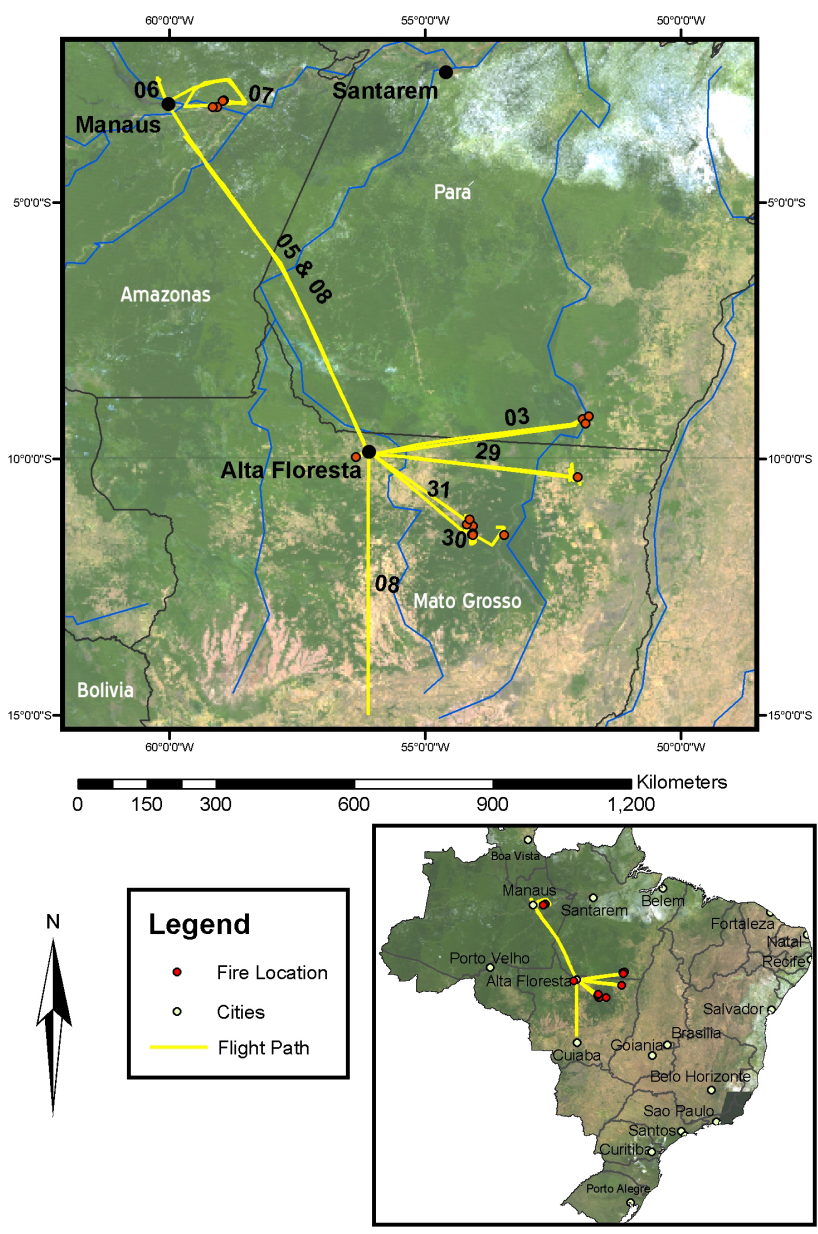

Fig. 1. The TROFFEE flight tracks and the locations of the fires sampled.

Andreae, 1990), 34\% (Hao and Liu, 1994), and 15\% (Andreae and Merlet, 2001). Thus, factors of 2-3 uncertainty need to be resolved, but these fires consistently emerge as one of the three major types of burning along with savanna fires and domestic biofuel use. A large uncertainty in the estimated area burned is due to uncertainties in remote sensing applications. For example, it is unclear if small fires or understory fires can be quantified from space (Brown et al., 2006), and many fires can be missed from space due to cloud cover, which is common over tropical forested regions. Deforestation fires facilitate land-use change, which alters the biogenic emissions. Thus, to understand regionalglobal atmospheric chemistry and assess the long-term impact of land-use change, we must thoroughly characterize the smoke emissions from these fires and the different biogenic emissions produced by the primary forest and the various anthropogenic "replacement" ecosystems.

The Tropical Forest and Fire Emissions Experiment (TROFFEE) provided emissions measurements for tropical deforestation fires and tropical vegetation. An overview of
TROFFEE follows. A laboratory experiment was carried out before the field campaigns that intercompared protontransfer reaction mass spectrometry (PTR-MS), open-path Fourier transform infrared spectroscopy (FTIR), and gas chromatography (GC) coupled to PTR-MS (GC-PTR-MS) on 26 fires burning tropical fuels. The laboratory work helped plan the PTR-MS sampling protocol for the field campaign and instrumentation was available to quantify some particle characteristics not measured in the field. The GC-PTR-MS measured the branching ratios for fire-emitted species that appear on the same mass channel. The laboratory fire and intercomparison results are presented elsewhere (Karl et al., 2007a; Christian et al., 2007a $\mathrm{a}^{1}$ ).

The TROFFEE field campaigns were in Brazil since it has the most tropical forest and the most deforestation fires. The ground-based field campaigns included measurements of biogenic emissions from pristine forest near Manaus (Fig. 1) (Karl et al., 2007b). The ground campaign also included FTIR emissions measurements on initially-unlofted plumes from 9 biomass fires in the vicinity of Alta Floresta (Fig. 1). These plumes were due to residual smoldering combustion at deforestation sites or pasture maintenance burns or they were from charcoal kilns, cooking fires, burning dung, etc. This element of TROFFEE was motivated by indications from previous field campaigns that initially, unlofted biomass burning plumes might contribute a large portion of the total regional emissions (Kauffman et al., 1998; Reid et al., 1998). The results for unlofted plumes and biofuels are described by Christian et al. (2007b). The ground campaign fires included a planned fire in which Brazilian researchers carried out a "typical" deforestation burn under conditions where the fuel consumption and other aspects of fire ecology could be measured. The emissions from this planned fire were measured by the ground-based FTIR and in the TROFFEE airborne campaign (described next).

The TROFFEE airborne campaign (Fig. 1) consisted of 44.5 flight hours between 27 August and 8 September of 2004 on an Embraer Bandeirante operated by the Brazilian National Institute for Space Research (Instituto Nacional de Pesquisas Espaciais (INPE)). The major instruments deployed on the aircraft included: (1) real-time ozone, condensation particle counter, and mass-calibrated nephelometry (University of São Paulo); (2) PTR-MS (National Center for Atmospheric Research); (3) Whole air sampling in canisters with subsequent GC analysis using flame ionization, mass selective, and electron capture detection (FID, MSD, and ECD; University of California at Irvine); and (4) airborne FTIR (University of Montana). This suite of instruments was well suited for measuring $\mathrm{CO}_{2}, \mathrm{CO}, \mathrm{PM}_{10}, \mathrm{CH}_{4}, \mathrm{NO}_{\mathrm{x}}, \mathrm{O}_{3}$,

\footnotetext{
${ }^{1}$ Christian, T. J., Karl, T. G., Yokelson, R. J., Guenther, A., and Hao, W. M.: The tropical forest and fire emissions experiment: Laboratory fire measurements and synthesis of campaign data, Atmos. Chem. Phys. Discuss., in preparation, 2007a.
} 
Table 1. Location and characteristics of fires sampled from the INPE Bandeirante aircraft during TROFFEE 2004 airborne campaign.

\begin{tabular}{|c|c|c|c|c|c|c|}
\hline \multirow[b]{3}{*}{ Fire name } & \multicolumn{5}{|c|}{ Source location } & \multirow{3}{*}{ Fuels observed from aircraft } \\
\hline & \multirow{2}{*}{$\begin{array}{c}\text { Date } \\
\mathrm{dd} / \mathrm{mm}\end{array}$} & \multirow{2}{*}{$\begin{array}{c}\text { Lat } \\
\text { dd.ddd }\end{array}$} & \multirow{2}{*}{$\begin{array}{l}\text { Long } \\
\text { dd.ddd }\end{array}$} & \multicolumn{2}{|c|}{ time period sampled } & \\
\hline & & & & LT & LT & \\
\hline 29 Aug Fire 1 & $29 / 08$ & -10.270 & -52.159 & $13: 41: 54$ & $14: 17: 10$ & slash under partial canopy \\
\hline 29 Aug Fire 2 & $29 / 08$ & -10.357 & -52.019 & $14: 30: 37$ & $14: 43: 30$ & Pasture \\
\hline 30 Aug Fire 1 & $30 / 08$ & -11.315 & -54.064 & $12: 56: 51$ & $13: 00: 45$ & grass and slash piles under partial canopy \\
\hline 30 Aug Fire 2 & $30 / 08$ & -11.459 & -54.062 & $13: 04: 18$ & $13: 13: 37$ & grass and slash piles under partial canopy \\
\hline 30 Aug Fire 3 & $30 / 08$ & -11.479 & -54.088 & $13: 20: 14$ & $13: 20: 55$ & grass and slash piles under partial canopy \\
\hline 30 Aug Fire 4 & $30 / 08$ & -11.491 & -54.058 & $13: 29: 06$ & $13: 36: 56$ & grass and slash piles under partial canopy \\
\hline SC Fire & $30 / 08$ & -11.488 & -53.458 & $14: 36: 25$ & $14: 43: 59$ & mixed forest fuels \\
\hline 31 Aug Fire 1 & $31 / 08$ & -11.282 & -54.185 & 13:08:58 & $13: 25: 01$ & mixed forest fuels \\
\hline 31 Aug Fire 2 & $31 / 08$ & -11.183 & -54.131 & $13: 30: 55$ & $13: 44: 52$ & mixed forest fuels \\
\hline 3 Sept Fire 1 & 03/09 & -9.224 & -51.918 & $13: 23: 32$ & $13: 39: 36$ & mixed forest fuels \\
\hline 3 Sept Fire 2 & 03/09 & -9.167 & -51.798 & $13: 37: 00$ & $13: 37: 08$ & mixed forest fuels \\
\hline 3 Sept Fire 3 & 03/09 & -9.311 & -51.861 & $13: 52: 24$ & $14: 02: 22$ & mixed forest fuels \\
\hline 3 Sept Fire 4 & 03/09 & \multicolumn{2}{|c|}{$\mathrm{nm}$} & $14: 13: 48$ & $14: 14: 16$ & source/fuels not observed from aircraft \\
\hline 3 Sept Fire 5 & 03/09 & \multicolumn{2}{|c|}{$\mathrm{nm}$} & $13: 22: 41$ & $13: 22: 54$ & source/fuels not observed from aircraft \\
\hline Planned Fire & $05 / 09$ & -9.969 & -56.345 & $14: 16: 42$ & $14: 51: 08$ & mixed forest fuels \\
\hline 7 Sept Fire 1 & $07 / 09$ & -3.007 & -8.930 & $11: 49: 39$ & $11: 56: 42$ & mixed forest fuels \\
\hline 7 Sept Fire 2 & $07 / 09$ & -3.011 & -58.946 & $12: 01: 13$ & $12: 01: 29$ & mixed forest fuels \\
\hline 7 Sept Fire 3 & $07 / 09$ & -3.129 & -59.056 & 12:04:50 & $12: 05: 58$ & mixed forest fuels \\
\hline 7 Sept Fire 4 & $07 / 09$ & -3.137 & -59.147 & $12: 06: 46$ & $12: 07: 36$ & mixed forest fuels \\
\hline Mega-plume & 08/09 & \multicolumn{2}{|c|}{$\mathrm{nm}$} & $\sim 11: 00$ & $\sim 12: 30$ & source/fuels not observed from aircraft \\
\hline
\end{tabular}

and $>40$ non-methane organic compounds (NMOC) including the important biogenic emissions isoprene and methanol.

In phase 1, the aircraft was based in Alta Floresta, Mato Grosso in the southern Amazon (9.917 S, 56.017 W, Fig. 1) from 27 August-5 September where the local dry/burning season was well underway. Regional haze due mostly to diluted biomass-burning smoke of unknown age and the nascent (minutes-old) emissions from 15 fires (mostly deforestation fires) were sampled in the states of Mato Grosso and Pará within about one-hour flight time $(\sim 300 \mathrm{~km})$ of Alta Floresta.

In phase 2, the aircraft was based in Manaus, Amazonas (3.039 S, 60.050 W, Fig. 1) from 5-8 September. The local dry season was just beginning there and the air was much cleaner and mostly unaffected by fires; especially in the mornings. The biogenic emissions were sampled from forests, several plantations east of Manaus, and the pristine forest at the ZF-14 tower north of Manaus. The results are discussed and integrated with the ground-based biogenic measurements by Karl et al. (2007b). In addition, four more fires were sampled around noon in the Manaus region. On 8 September from $8-13^{\circ} \mathrm{S}$ we sampled a smoke plume hundreds of $\mathrm{km}$ wide that contained the combined emissions from a huge number of fires. These fires represented a significant fraction of the total Amazon burning for 2004 and they generated a "mega-plume," which we discuss in detail in Sect. 3.4. All the fires sampled are listed in Table 1. The
TROFFEE flight tracks and individual fires are mapped in Fig. 1. A more detailed map of the 6-7 September flights is given by Karl et al. (2007b).

The fire component of TROFFEE is covered in four initial papers. The lab fire results and the chemistry and impact of unlofted smoke not amenable to airborne sampling are covered in two papers (Christian et al., 2007a ${ }^{1}$, b). Karl et al. (2007a) present the instrument intercomparison and the emission ratios of many VOC to acetonitrile, which is thought to be mostly emitted by biomass burning. The main focus of this paper is to provide background on the region and experiment and to detail the airborne measurements of fire emission factors, which are needed as model input and for bottom-up emissions estimates at any scale. Some aspects of the airborne measurements in clean air (relatively unaffected by fires) and haze (dilute/aged smoke) are also given to clarify the regional atmospheric conditions and make our fire-sampling strategy clear.

A major goal of all the TROFFEE fire research was comprehensive sampling of reactive species as close as possible to the source. The rationale for this is given next. Much of the initial interest in fires focused on the climate forcing. In fact, in El-Niño years, the carbon added to the atmosphere by biomass burning may exceed that from fossil fuels (Page et al., 2002). The $\mathrm{CO}_{2}$ due to tropical deforestation alone may cause an average annual amount of warming that is $20-60 \%$ of that caused by the $\mathrm{CO}_{2}$ from all global 
industry (Crutzen and Andreae, 1990) and fires emit more other greenhouse gases (GHG) per $\mathrm{CO}_{2}$ than fossil fuel use (Christian et al., 2003). Photochemical processing of fire emissions was shown to produce $\mathrm{O}_{3}$ (Fishman et al., 1991; Andreae et al., 1994), an important GHG (Prather et al., 1994). Particles emitted by fires were found to cause negative forcing both directly (Hobbs et al., 1997) and indirectly by reducing cloud droplet sizes and increasing cloud albedo (Kaufman and Fraser, 1997).

In recent years, the reactivity and the rapid post-emission chemistry of smoke have attracted increasing attention. Early laboratory and field studies of biomass burning had concentrated on measuring the emissions of $\mathrm{CO}_{2}, \mathrm{CO}, \mathrm{NO}_{\mathrm{x}}$, and hydrocarbons (Lobert et al., 1991; Blake et al., 1996; Ferek et al., 1998), but later laboratory work showed that 60-80\% of the NMOC emissions from fires were actually highly reactive, oxygenated VOC (OVOC) (Yokelson et al., 1996, 1997; Holzinger et al., 1999). The dominance of NMOC emissions by OVOC was then confirmed for all of the major types of biomass burning except tropical forest fires: e.g. savannas, biofuels, agricultural waste, peat, and boreal forest (Goode et al., 2000; Christian et al., 2003; Bertschi et al., 2003a). In addition, field measurements of rapid changes in smoke plume chemistry became available (Goode et al., 2000; Yokelson et al., 2003a; Hobbs et al., 2003). Detailed photochemical smoke models reproduced the observed $\mathrm{O}_{3}$ formation rate in only some cases and were unable to predict the observed formation of other species such as acetone and acetic acid (Mason et al., 2001; Jost et al., 2003; Tabazadeh et al., 2004; Trentmann et al., 2005). Sensitivity analysis showed that model performance was significantly enhanced by using more complete information on the initial NMOC (mostly OVOC) emissions. About $80 \%$ of biomass burning occurs in the tropics, which govern the oxidizing power of the global troposphere (Crutzen and Andreae, 1990). Fires are a major source of $\mathrm{CO}$ (the main sink of $\mathrm{OH}$ ), but the large quantities of OVOC emitted by fires, and the secondary $\mathrm{O}_{3}$, are $\mathrm{HO}_{x}$ $\left(\mathrm{OH}+\mathrm{HO}_{2}\right)$ precursors and important oxidants (FinlaysonPitts and Pitts 1986; Singh et al., 1995). Thus there was a critical need for the first-ever data on OVOC emissions from tropical deforestation fires.

\section{Experimental details}

\subsection{Instrument details}

\subsubsection{Airborne FTIR (AFTIR) and whole air sampling in canisters}

The basic design and operation of the AFTIR system has been described in detail by Yokelson et al. (1999, 2003a, b). A summary description is given here followed by the details of how AFTIR was used to fill canisters. The AFTIR has a dedicated, halocarbon-wax, coated inlet that directs ram air through a Pyrex, multipass cell. Infrared spectra of the cell contents are acquired continuously (every $0.83 \mathrm{~s}$ ) throughout each flight and the flow-control valves are normally open, which flushes the cell with outside air every $2-4 \mathrm{~s}$. The fastacting flow control valves allow the system flow to be temporarily stopped for signal averaging and improved accuracy on "grab samples." The IR spectra are later analyzed to quantify the compounds responsible for all the major peaks. This accounts for most of the trace gases present in the cell above 5-20 ppbv (Goode et al., 1999).

For TROFFEE, a Teflon valve was added to the AFTIR cell that connected to two options for filling evacuated canisters. For a canister sample of a plume, we used a teflondiaphragm pump to pressurize the can with gas from the AFTIR cell, which already contained a grab sample of the plume. Pressurizing the cans allows more sensitive and/or a wider variety of analyses and also prevents contamination in the event of a slow leak. Operationally-simpler canister samples of background air were obtained by diverting a portion of the flow through the AFTIR cell into the cans. The .635 $\mathrm{cm}$ outside diameter Teflon tubing connecting to the canisters had a pressure higher than the cabin pressure and attached to the can with Ultra-Torr ${ }^{\circledR}$ fittings. We flushed the connecting tubing with cell air by loosening the fitting for a few minutes. Once the fitting was retightened the pre-evacuated can was opened and filled to cell pressure within seconds. The filling time of each can was shown by a sharp, (logged) pressure response in the AFTIR cell. The canisters were later analyzed at UCI using GC/FID-MSD-ECD (Colman et al., 2001).

\subsubsection{IR spectral analysis}

Mixing ratios for $\mathrm{H}_{2} \mathrm{O}, \mathrm{CO}_{2}, \mathrm{CO}$, and $\mathrm{CH}_{4}$ were obtained by multicomponent fits to sections of the IR transmission spectra with a synthetic calibration non-linear least-squares method (MALT 5.2) recently developed by one of the authors (Griffith). To derive excess mixing ratios $(\Delta \mathrm{X})$ for the above species in smoke plumes we took the mixing ratio of the species " $X$ " in the smoke plume grab sample minus the mixing ratio of $\mathrm{X}$ in the closest grab sample of background air. The use of a nearby background sample for this subtraction is important because it excludes the contribution of the aged smoke that contributes much of the background air in areas heavily impacted by biomass burning.

We used the same background-plume spectra pairs to generate absorbance spectra of the smoke plume samples. Excess mixing ratios are retrieved directly from the absorbance spectra (Hanst and Hanst, 1994). Excess mixing ratios for $\mathrm{NO}$ and $\mathrm{NO}_{2}$ in smoke plumes were obtained from the absorbance spectra using peak integration and a multipoint calibration. Excess mixing ratios for ethylene $\left(\mathrm{C}_{2} \mathrm{H}_{4}\right)$, acetylene $\left(\mathrm{C}_{2} \mathrm{H}_{2}\right)$, propylene $\left(\mathrm{C}_{3} \mathrm{H}_{6}\right)$, methanol $\left(\mathrm{CH}_{3} \mathrm{OH}\right)$, formic acid $(\mathrm{HCOOH})$, acetic acid $\left(\mathrm{CH}_{3} \mathrm{COOH}\right)$, ammonia $\left(\mathrm{NH}_{3}\right)$, nitrous acid (HONO), hydrogen cyanide $(\mathrm{HCN})$, and ozone 
$\left(\mathrm{O}_{3}\right)$ were retrieved from the absorbance spectra by spectral subtraction (Yokelson et al., 1997). The spectral subtraction routine used commercial IR reference spectra or multiple reference spectra per species that we recorded in house for $\mathrm{NH}_{3}$, $\mathrm{CH}_{3} \mathrm{OH}, \mathrm{CH}_{3} \mathrm{COOH}, \mathrm{C}_{2} \mathrm{H}_{4}$, and $\mathrm{C}_{3} \mathrm{H}_{6}$. Excess mixing ratios for $\mathrm{C}_{2} \mathrm{H}_{6}$ and $\mathrm{HCHO}$ were retrieved from the absorbance spectra using MALT 5.2. For most compounds the detection limit was 5-10 ppbv, but for $\mathrm{NO}_{\mathrm{x}}, \mathrm{HCHO}$, acetic acid, $\mathrm{C}_{3} \mathrm{H}_{6}$, $\mathrm{C}_{2} \mathrm{H}_{6}$, and $\mathrm{O}_{3}$ it was $\sim 15-20$ ppbv.

The spectral analysis routines were challenged by applying them to IR spectra of over 50 flowing standard mixtures. The routines typically returned values within $1 \%$ of the nominal, delivered amount. Consideration of the accuracy of the standards, flow meters, and other issues suggests that the absolute accuracy of our mixing ratios is $\pm 1-2 \%$ for $\mathrm{CO}_{2}, \mathrm{CO}$, and $\mathrm{CH}_{4}$ and $\pm 5 \%(1 \sigma)$ or the detection limit, whichever is larger, for the other compounds. $\mathrm{NH}_{3}$ was the only compound noticeably affected by brief storage in the cell, but the $\mathrm{NH}_{3}$ values have been corrected both for initial passivation of the cell and slow decay during grab-sample storage as described by Yokelson et al. (2003b) and should be accurate to $\pm 10 \%$ or the detection limit.

\subsubsection{PTR-MS}

A detailed description of the PTR-MS instrument is given elsewhere (Lindinger et al., 1998). Briefly, $\mathrm{H}_{3} \mathrm{O}^{+}$ions are used to ionize volatile organic compounds (VOC) via protontransfer reactions. The value for $\mathrm{E} / \mathrm{N}$ ( $\mathrm{E}$ the electric field strength and $\mathrm{N}$ the buffer gas density) in the drift tube was kept at about 123 Townsend, which is high enough to avoid strong clustering of $\mathrm{H}_{3} \mathrm{O}^{+}$ions with water and thus a humidity dependent sensitivity. The sensitivity of the PTR-MS instrument during this study was typically on the order of $70 \mathrm{~Hz} / \mathrm{ppbv}$ (counts per second per ppbv) for acetone and $50 \mathrm{~Hz} / \mathrm{ppbv}$ for methanol at $2.3 \mathrm{mbar}$ buffer gas pressure with a reaction time of $110 \mu \mathrm{s}$ and $3-4 \mathrm{MHz} \mathrm{H}_{3} \mathrm{O}^{+}$ions, and thus inferred a signal to noise ratio of $60 \%$ at a concentration of 20 pptv and a $2 \mathrm{~s}$ integration time. The PTR-MS sampled air through a dedicated, rear-facing, Teflon inlet. About 17 mass channels were monitored during flight with a measurement period for each species of 1-20 s. Higher sampling rates were used in the plumes. More details about the PTR-MS in this campaign are given by Karl et al. (2007a).

\subsubsection{Particle, ozone, and auxiliary measurements}

A list of the instruments deployed by the University of São Paulo and their measurement frequency follows. (1) DataRAM4 (Thermoelectron Corp), which measures the mass of particles with an aerodynamic diameter $<10 \mathrm{mi}-$ crons $\left(\mathrm{PM}_{10}\right)$ and mean particle diameter (microns) at $0.5 \mathrm{~Hz}$. (2) 3-channel nephelometer (RBG) at $0.2857 \mathrm{~Hz}$. (3) 7 channel aethalometer (Magee Scientific) measuring particle absorbance from $950-450 \mathrm{~nm}$ every $2 \mathrm{~min}$. (4) Ozone by UV absorbance (1 min time resolution). (5) GPS (Garmin) measuring UTC time, latitude, longitude, and altitude at $1 \mathrm{~Hz}$. Instruments 1-4 had specialized inlets located on the front belly of the aircraft adjacent to the PTR-MS inlet. The $\mathrm{PM}_{10}$ measurements reported here were measured by the DataRAM4, which is a two-wavelength nephelometer with a built in humidity correction. The instrument has been run side by side with a TEOM (Tapered Element Oscillating Microbalance) under smoky conditions in the Amazon and good agreement was observed.

\subsubsection{Flight plans and sampling protocols}

While based in Alta Floresta (27 August-5 September) background air (defined here as air not within a visible biomass burning plume) was characterized at various altitudes (up to $3352 \mathrm{~m}$ ). These were afternoon flights conducted to search for and sample fires and most of the measurements were made below the top of the (hazy) mixed layer. While based in Manaus cleaner background air was sampled during morning flights over a similar altitude range. The Manaus flights included both continuous-spiral and "parking-garage"-type vertical profiles over the instrumented ZF-14 Tower and a constant-altitude "racetrack" pattern that sampled several regionally important ecosystems (undisturbed forest, flooded forest, and various plantations) east of Manaus (Karl et al., 2007b). When sampling background air in either region, the PTR-MS continuously cycled through a suite of mass channels with a resulting measurement frequency for individual species ranging from 10-20 s. Overall, twenty-one canisters were used to "grab" background samples at key locations. The airborne FTIR (AFTIR) was operated either continuously (time resolution of 0.83 to $18 \mathrm{~s}$ ) or to acquire 133 grab samples of background air.

To measure the initial emissions from fires in both regions, we sampled smoke less than several minutes old by penetrating the column of smoke $200-1000 \mathrm{~m}$ above the flame front. The AFTIR system and cans obtained grab samples in the plume (and paired background samples just outside the plume). The other instruments measured their species continuously while passing through the plume. More than a few kilometers downwind from the source, smoke plume samples are "chemically aged" and better for probing postemission chemistry than estimating initial emissions (Hobbs et al., 2003; de Gouw et al., 2006).

\subsection{Data processing and synthesis}

Grab samples or profiles of an emission source can provide excess mixing ratios $(\Delta X$, see Sect. 2.1.2). $\Delta X$ reflect the instantaneous dilution of the plume and the instrument response time. Thus, a widely used, derived quantity is the normalized excess mixing ratio where $\Delta \mathrm{X}$ is compared to a simultaneously measured plume tracer such as $\Delta \mathrm{CO}$ or $\Delta \mathrm{CO}_{2}$. A measurement of $\Delta \mathrm{X} / \Delta \mathrm{CO}$ or $\Delta \mathrm{X} / \Delta \mathrm{CO}_{2}$ made in 
a nascent plume (seconds to a few minutes old) is an emission ratio (ER). The ER $\Delta \mathrm{CO} / \Delta \mathrm{CO}_{2}$ and the modified combustion efficiency (MCE, $\Delta \mathrm{CO}_{2} /\left(\Delta \mathrm{CO}_{2}+\Delta \mathrm{CO}\right)$ ) are useful to indicate the relative amount of flaming and smoldering combustion for biomass burning. Higher $\Delta \mathrm{CO} / \Delta \mathrm{CO}_{2}$ or lower MCE indicates more smoldering (Ward and Radke, 1993). For any carbonaceous fuel, a set of $\mathrm{ER}$ to $\mathrm{CO}_{2}$ for the other major carbon emissions (i.e. $\mathrm{CO}, \mathrm{CH}_{4}$, a suite of NMOC, particulate carbon) can be used to calculate emission factors (EF, g compound emitted/kg dry fuel) for all the gases quantified from the source using the carbon mass-balance method (Yokelson et al., 1996). EFs are combined with fuel consumption measurements to estimate total emissions at various scales. In this project, the primary data needed to calculate EF was provided by AFTIR measurements of $\mathrm{CO}_{2}, \mathrm{CO}$, $\mathrm{CH}_{4}$, and many NMOC. However, the PTR-MS and canister sampling added numerous, important NMOC that were below AFTIR detection limits or not amenable to IR detection. The $\mathrm{PM}_{10}$ data allowed inclusion of particle carbon. Next we summarize the methods we used to calculate ER and EF and to couple/synthesize the data from the various instruments on the aircraft.

\subsubsection{Estimation of fire-average, initial emission ratios} (ER)

The first step in our analysis was to compute molar ER to CO and $\mathrm{CO}_{2}$ for each species detected in the AFTIR or can grab samples; and molar ER to methanol (justified below) for each species detected by PTR-MS. This is done for each individual fire or each group of co-located, similar fires. If there is only one sample of a fire (as for the canisters) then the calculation is trivial and equivalent to the definition of $\Delta \mathrm{X}$ given above. For multiple AFTIR grab samples of a fire (or group of fires) then the fire-average, initial ER were obtained from the slope of the least-squares line (with the intercept forced to zero) in a plot of one set of excess mixing ratios versus another (see Figs. 2a and b). This method is justified in detail by Yokelson et al. (1999). We calculated the fire-average $\mathrm{MCE}$ for each fire using the fire-average $\Delta \mathrm{CO} / \Delta \mathrm{CO}_{2}$ and the equation $\mathrm{MCE}=1 /\left(\left(\Delta \mathrm{CO} / \Delta \mathrm{CO}_{2}\right)+1\right)$.

The ER for PTR-MS compounds with respect to methanol were obtained by similar plots except that the integrated excess mixing ratios (ppbv s) for each pass thru the plume were used in lieu of the individual excess mixing ratios (see Fig. 2c). Comparison of integrals provides more accurate ER (Karl et al., 2007a). When two or more compounds appear on the same mass channel, the signal was assigned to each compound using the branching ratios measured by GC-PTR-MS in smoke from tropical fuels burned during the lab experiment. This adds additional uncertainty for these compounds since these branching ratios typically varied by $10-20 \%$ from fire to fire during the lab experiments (Karl et al., 2007a).

The ER to CO for the NMOC detected by PTR-MS was derived from a simple two step process. The process is based on the fact that we have found excellent agreement between FTIR and PTR-MS for methanol, over a wide range of concentrations, in two other studies (Christian et al., 2004; Karl et al., 2007a). An example of the process follows. The ER for acetaldehyde to $\mathrm{CO}$ was taken to be the PTR-MS ER "acetaldehyde/methanol" times the AFTIR ER "methanol/CO." Multiplying again by the AFTIR $\mathrm{CO} / \mathrm{CO}_{2}$ ratio gave the ratio of the NMOC to $\mathrm{CO}_{2}$ - as needed for the EF calculation. A slightly different approach was needed to couple the data from the particle instruments. The DataRAM4 measures the STP-equivalent $\mathrm{PM}_{10}$ per unit volume $\left(\mu \mathrm{g} / \mathrm{m}^{3}\right)$ every two seconds while passing thru a plume. We converted the integrated methanol mixing ratios to an integrated mass (STP) of methanol and ratioed the integrated particle mass to this (see Fig. 2d).

\subsubsection{Estimation of fire-average, initial emission factors}

We estimated fire-average, initial $\mathrm{EF}$ for $\mathrm{PM}_{10}$ and each observed trace gas from our fire-average, initial ER using the carbon mass balance method (Ward and Radke, 1993) as described by Yokelson et al. (1999). Briefly, we assume that all the volatilized carbon is detected and that the fuel carbon content is known. For purposes of the carbon mass balance we assume the particles are $60 \% \mathrm{C}$ by mass (Ferek et al., 1998). By ignoring unmeasured gases we are probably inflating the emission factors by 1-2\% (Andreae and Merlet, 2001). We assumed in our EF calculations that all the fires burned in fuels containing $50 \%$ carbon by mass. This is in good agreement with previous studies of tropical biomass (Susott et al., 1996), but the actual fuel carbon percentage may vary by $\pm 10 \%(2 \sigma)$ of our nominal value. (Emission factors scale linearly with assumed fuel carbon percentage.)

\subsection{Overview of Brazilian fires and the fires sampled in the airborne campaign}

\subsubsection{General fire characteristics relevant to sampling strategies}

Conversion of the Amazon primary forest usually starts at the beginning of the dry season (May-July) when the biomass is slashed and dried (Fearnside, 1993). Most of the burns occur late in the dry season (August-October) to achieve high consumption. A typical burn is initiated by starting a line of flame along the outer edge of the slashed area. As the flame front propagates inward, the flame-induced convection column entrains the emissions from both flaming combustion and any nearby smoldering combustion. These emissions can be sampled from an aircraft. In some cases, smoldering can continue after the convection envelope has moved too far away to entrain the emissions or convection from the entire site has ceased. When either of these conditions is met, we term this residual smoldering combustion (RSC). RSC emissions are not initially lofted or amenable to airborne 

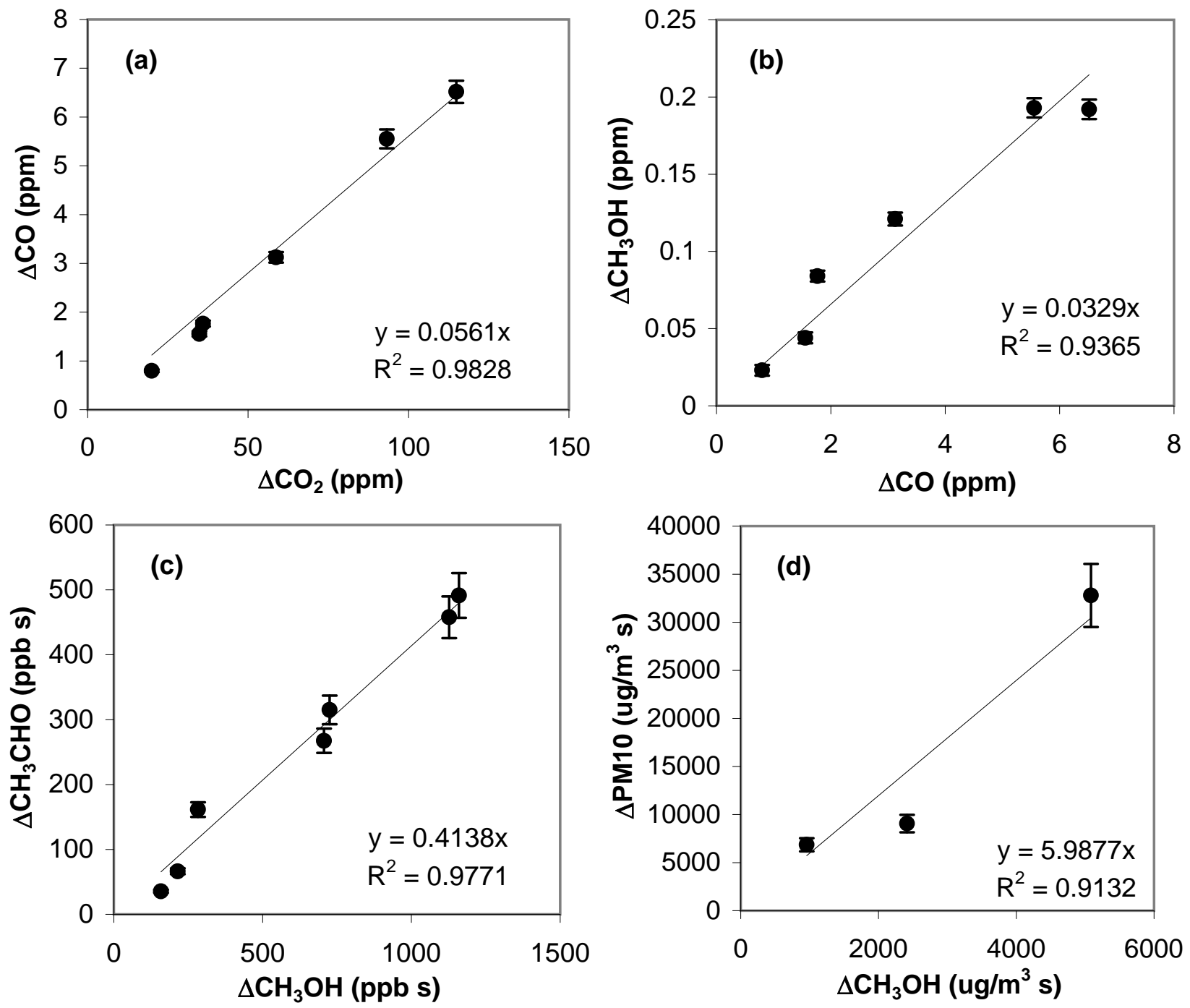

Fig. 2. Examples of the plots used to derive emission ratios (ER) in this work. See Sect. 2.2.1 for details. (a) plot used to derive the ER $\Delta \mathrm{CO} / \Delta \mathrm{CO}_{2}$ from AFTIR grab samples of the 5 September planned fire. (b) as in a for the ER $\Delta \mathrm{CH} \mathrm{H}_{3} \mathrm{OH} / \Delta \mathrm{CO}$. (c) plot for the ER $\Delta \mathrm{CH}_{3} \mathrm{CHO} / \Delta \mathrm{CH}_{3} \mathrm{OH}$ from integrated PTR-MS traces during plume penetrations of the 5 September fire. (d) plot used to derive the ER $\Delta \mathrm{PM}_{10} / \Delta \mathrm{CH}_{3} \mathrm{OH}$ (mass ratio) from integrated PTR-MS and nephelometer traces during plume penetrations of the shifting cultivation fire on 30 August.

sampling. When dry, large-diameter fuels are present RSC may account for a large part of the total biomass consumed (Bertschi et al., 2003b; Kauffman et al., 1998).

\subsubsection{Overview of Brazilian biomass burning}

This section summarizes Brazilian biomass burning to help assess the representativeness of the fires we actually sampled. Brazil contains $\sim 2 \times 10^{6} \mathrm{~km}^{2}$ of savanna (cerrado), mostly in southern Brazil, which is burned every $1-3$ years in fires that rapidly consume $5-10 \mathrm{Mg} / \mathrm{ha}$ of mostly fine fuels such as grass (Coutinho, 1990; Ward et al., 1992; Kauffman et al., 1994; Andrade et al., 1999). For estimating the emissions from any global savanna fire, we recommend the tables for savanna fires in Christian et al. (2003) and Andreae and Merlet (2001).

Brazil has $\sim 4 \times 10^{6} \mathrm{~km}^{2}$ of evergreen tropical forest mostly in the Amazon basin, which represents $\sim 25 \%$ of the world's total "rainforest." Deforestation rates in the Amazon since 1978 ranged from $11-29 \times 10^{3} \mathrm{~km}^{2} / \mathrm{y}$ (http://www.obt. inpe.br/prodes/). About $85 \%$ of the cumulative deforested area for 1978-2005 occurred in the rapidly developing southern and eastern edges of the Amazon basin where the states of Pará and Mato Grosso are located (Fig. 1). Deforestation fires involve large total aboveground biomass (TAGB) 
loading averaging $\sim 300 \mathrm{Mg} / \mathrm{ha}$ of which $\sim 40 \%$ is consumed by the fires for a total fuel consumption of $\sim 120 \mathrm{Mg} / \mathrm{ha}$. (Ward et al., 1992; Fearnside et al., 1993; Carvalho et al., 1998, 2001; Guild et al., 1998).

Pastures established in previously forested areas of the Amazon are maintained by burning every $2-3$ years (Guild et al., 1998). The TAGB can be quite large partly because residual wood debris (RWD) persists for many years. Reported TAGB ranges from $119 \mathrm{Mg} / \mathrm{ha}(87 \% \mathrm{RWD})$ to $53 \mathrm{Mg} / \mathrm{ha}$ (47\% RWD) in pastures 4-20 years old (Barbosa and Fearnside, 1996; Guild et al., 1998; Kauffman et al., 1998). Largediameter RWD accounted for $\sim 45 \%$ of the fuel consumption in the above studies. Until recently, nearly all deforested areas in the Brazilian Amazon were eventually converted to pasture and the total emissions from Brazilian pasture fires are thought to be comparable to the total emissions from Brazilian deforestation fires (Fearnside, 1990; Barbosa et al., 1996; Kauffman et al., 1998). Globally, deforestation fires associated with shifting cultivation and plantation establishment dominate and pasture fires are relatively less common.

Brazil has recently seen explosive growth in large-scale, mechanized agriculture, especially in Mato Grosso (Cardille and Foley, 2003). Both pastures and forest are converted to croplands for (mostly) soy. In either case, all large-diameter fuels must be removed by the burns. Morton et al. (2006) found that Mato Grosso accounted for $40 \%$ of the new deforestation in Amazonia from 2000-2004. Within Mato Grosso from 2001-2004, pasture was still the main use following deforestation, but that fraction was decreasing and direct transition to large areas of cropland accounted for $23-28 \%$ of deforestation. Thus, we conclude that the expansion of mechanized agriculture could imply an increase in both the area of individual fires and the fuel consumed per unit area.

A few other less dominant fire-types occur in Brazil. Secondary forests are used in similar fashion to primary forests (Fearnside, 1990, 2000). Lower intensity fires occur naturally in seasonally dry forests, such as the Caatinga in eastern Brazil and these forests are also subject to land-use change (Kauffman et al., 1993). Selective logging promotes fire susceptibility and is increasing in the Amazon (Grainger, 1987; Kauffman and Uhl, 1990; Cochrane et al. 1999; Laurance, 2000).

As discussed in detail by Christian et al. (2007b), RSC could produce a large part of the Amazonian fire emissions and this motivated our simultaneous airborne and ground based campaigns. However, RSC likely occurs mostly on pasture maintenance fires rather than the deforestation fires, which were our main target.

\subsubsection{Description of the fires sampled in the airborne cam- paign}

Nearly all the fires we observed in Mato Grosso and southern Pará were related to the expansion of existing, large farms or ranches (Table 1). All but 3 of these fires were located on the edge of forested areas that were adjacent to large tracts of cleared, often cultivated, land. Casual examination of MODIS visible images of this region reveals that nearly all hotspots are located at the edge of dark-green (forested) areas, adjacent to light-green (cleared) areas (http://rapidfire.sci.gsfc.nasa.gov/ subsets/?AERONET_Alta_Floresta/2004252). However, the second fire sampled on 29 August was in a grass meadow and no large fuels were visible from the air. This was probably a maintenance fire for an older pasture. The other exception was two small fires observed on 31 August adjacent to the Xingu River in the center of an indigenous reserve and far from any visible clearings or roads. These fires were likely due to shifting cultivation and the one we sampled is labeled the "SC" fire in Tables 1 and 2. Complete burning of logging slash to prepare for mechanized agriculture can be promoted by bulldozing the fuel into long piles ("windrows") that were observed from the aircraft on at least one group of fires (30 August Fires 1-4). In all areas, the fires frequently occurred in clusters.

TROFFEE supported a planned, deforestation fire on a farm near Alta Floresta under the supervision of João Carvalho (University of Estadual Paulista) and Ernesto Alvarado (University of Washington). Measurements included fuel consumption, charcoal production, propagation of smoldering combustion, forest flammability adjacent to clearcuts, onsite meteorology, fire effects on groundwater chemistry, and recovery and regeneration of burned areas. The emissions from this fire were sampled by ground-based FTIR (Christian et al., 2007b) and the TROFFEE aircraft (5 September data in Tables 1 and 2). In summary, pasture fires were undersampled relative to their importance in Brazil, but we achieved our objective of comprehensive chemical sampling of the emissions from deforestation fires, which are far more significant globally.

\section{Results and discussion}

\subsection{Characteristics of clean background air}

We briefly summarize some of the data obtained in early dry season, clean air near Manaus (see also Karl et al., 2007b). These data are of intrinsic interest and by comparison to data from the more active burning region further south (Sect. 3.2), they highlight the degree to which fires can perturb background air over a large geographic area. Figure 3a shows all the AFTIR CO grab samples from 6 and 7 September, obtained in the Manaus region, which was not visibly impacted by a biomass burning haze before noon. The $\mathrm{CO}$ average was $134 \pm 13 \mathrm{ppbv}$. This is a relatively narrow range. Chou et al. (2002) measured numerous CO vertical profiles in nearly the same location in April-May 1987. Their figures indicate that their $\mathrm{CO}$ values averaged about $100 \mathrm{ppb}$. The larger values we observed could be due to a gradual 
Table 2. Initial emission factors for the fires sampled at their source during the 2004 TROFFEE airborne campaign. Effective emission factors for the mega-plume, which was sampled downwind from source.

\begin{tabular}{|c|c|c|c|c|c|c|c|c|c|c|c|c|c|}
\hline $\begin{array}{l}\text { Compound } \\
\text { formula or name }\end{array}$ & $\begin{array}{c}29 \text { Aug } \\
\text { Fire } 1\end{array}$ & $\begin{array}{l}29 \text { Aug } \\
\text { Fire } 2\end{array}$ & $\begin{array}{l}30 \text { Aug } \\
\text { Fires 1-4 }\end{array}$ & $\begin{array}{l}30 \text { Aug } \\
\text { SC Fire }\end{array}$ & $\begin{array}{l}31 \mathrm{Aug} \\
\text { Fire } 1\end{array}$ & $\begin{array}{l}31 \text { Aug } \\
\text { Fire } 2\end{array}$ & $\begin{array}{l}3 \text { Sep } \\
\text { Fires 1-5 }\end{array}$ & $\begin{array}{c}5 \text { Sep } \\
\text { Planned } \\
\text { Fire } \\
\text { EF } \\
\mathrm{g} / \mathrm{kg}\end{array}$ & $\begin{array}{c}7 \mathrm{Sep} \\
\text { Fires } 1-4 \\
\text { EF } \\
\mathrm{g} / \mathrm{kg}\end{array}$ & $\begin{array}{c}\text { Study } \\
\text { average } \\
\mathrm{EF} \\
\mathrm{g} / \mathrm{kg}\end{array}$ & $\begin{array}{c}\text { Standard } \\
\text { deviation } \\
\mathrm{EF} \\
\mathrm{g} / \mathrm{kg}\end{array}$ & $\begin{array}{c}\text { Effective EF } \\
\mathrm{g} / \mathrm{kg}\end{array}$ & $\begin{array}{l}\text { MPEEF- } \\
\text { average }^{\mathrm{c}} \\
\text { \# stdev's }\end{array}$ \\
\hline \multicolumn{14}{|l|}{ AFTIR species } \\
\hline $\mathrm{CO}_{2}$ & 1638 & 1591 & 1567 & 1579 & 1603 & 1636 & 1579 & 1679 & 1662 & 1615 & 40 & 1651 & 0.91 \\
\hline $\mathrm{CO}$ & 95.72 & 112.08 & 133.45 & 124.82 & 110.70 & 93.13 & 110.52 & 59.91 & 72.36 & 101.41 & 23.78 & 87.54 & -0.58 \\
\hline MCE & 0.916 & 0.900 & 0.882 & 0.890 & 0.902 & 0.918 & 0.901 & 0.947 & 0.936 & 0.910 & 0.021 & 0.923 & 0.61 \\
\hline NO & 0.283 & $\mathrm{~nm}^{\mathrm{b}}$ & 0.281 & 0.514 & 0.208 & 0.438 & 0.746 & 2.681 & $\mathrm{~nm}$ & 0.74 & 0.877 & 2.297 & 1.78 \\
\hline $\mathrm{NO}_{2}$ & 1.979 & 0.930 & 1.157 & 0.509 & 0.738 & 2.216 & 1.393 & 3.441 & 4.120 & 1.83 & 1.245 & 1.899 & 0.05 \\
\hline $\mathrm{NO}_{\mathrm{x}}$ (as NO) & 1.574 & 0.606 & 1.035 & 0.846 & 0.690 & 1.883 & 1.654 & 4.926 & 2.687 & 1.77 & 1.359 & 3.535 & 1.30 \\
\hline HONO & 0.345 & 0.167 & $\mathrm{~nm}$ & $\mathrm{~nm}$ & $\mathrm{~nm}$ & $\mathrm{~nm}$ & $\mathrm{~nm}$ & $\mathrm{~nm}$ & $\mathrm{~nm}$ & 0.26 & 0.126 & $\mathrm{~nm}$ & $\mathrm{~nm}$ \\
\hline $\mathrm{CH}_{4}$ & 4.213 & 6.916 & 5.751 & 7.544 & 5.323 & 5.486 & 7.220 & 3.353 & 5.324 & 5.68 & 1.380 & 7.636 & 1.42 \\
\hline $\mathrm{C}_{2} \mathrm{H}_{4}$ & 0.747 & 1.238 & 0.958 & 1.215 & 0.997 & 0.809 & 1.520 & 0.642 & 0.454 & 0.95 & 0.332 & 0.378 & -1.73 \\
\hline $\mathrm{C}_{2} \mathrm{H}_{2}$ & 0.094 & $\mathrm{~nm}$ & 0.083 & 0.101 & 0.140 & 0.084 & 0.172 & 0.923 & 0.620 & 0.28 & 0.317 & 0.085 & -0.61 \\
\hline $\mathrm{C}_{2} \mathrm{H}_{6}$ & 0.548 & 1.137 & 0.917 & 1.157 & 0.893 & 0.532 & 1.478 & $\mathrm{~nm}$ & $\mathrm{~nm}$ & 0.95 & 0.341 & $\mathrm{~nm}$ & $\mathrm{~nm}$ \\
\hline $\mathrm{C}_{3} \mathrm{H}_{6}$ & 0.452 & 0.728 & 0.424 & 0.606 & 0.462 & 0.317 & 0.509 & 0.091 & $\mathrm{~nm}$ & 0.45 & 0.190 & $\mathrm{~nm}$ & $\mathrm{~nm}$ \\
\hline $\mathrm{HCHO}$ & 1.277 & 1.912 & 1.674 & 1.783 & 1.445 & 1.517 & 2.201 & 1.741 & 1.409 & 1.66 & 0.286 & 1.004 & -2.30 \\
\hline CH3OH & 2.077 & 2.874 & 2.724 & 3.371 & 2.294 & 2.331 & 3.002 & 2.252 & 2.165 & 2.57 & 0.445 & 2.550 & -0.04 \\
\hline $\mathrm{CH}_{3} \mathrm{COOH}$ & 3.134 & 4.172 & 3.635 & 3.590 & 2.643 & 3.232 & 3.190 & 3.579 & 3.704 & 3.43 & 0.436 & 9.242 & 13.33 \\
\hline $\mathrm{HCOOH}$ & 0.398 & 0.519 & 0.377 & 0.223 & 0.246 & 0.508 & 0.323 & 0.978 & 1.715 & 0.59 & 0.479 & 3.266 & 5.59 \\
\hline $\mathrm{NH}_{3}$ & 1.127 & 1.364 & 1.093 & 1.769 & 0.653 & 0.658 & 1.476 & 1.236 & 0.308 & 1.08 & 0.460 & 1.509 & 0.94 \\
\hline $\mathrm{HCN}$ & 0.665 & 0.537 & 0.699 & 0.582 & 0.486 & 0.409 & 0.426 & 2.098 & 0.184 & 0.68 & 0.555 & 0.169 & -0.91 \\
\hline \multicolumn{14}{|l|}{ PTR-MS species and $\mathrm{PM}_{10}$} \\
\hline acetaldehyde & 1.255 & 1.202 & 1.167 & 1.240 & 0.751 & 1.041 & 3.322 & 1.282 & 1.202 & 1.38 & 0.745 & $\mathrm{~nm}$ & $\mathrm{~nm}$ \\
\hline acrylonitrile & 0.051 & $\mathrm{~nm}$ & 0.038 & $\mathrm{~nm}$ & 0.020 & 0.048 & $\mathrm{~nm}$ & $\mathrm{~nm}$ & $\mathrm{~nm}$ & 0.04 & 0.014 & $\mathrm{~nm}$ & $\mathrm{~nm}$ \\
\hline acrolein & $\mathrm{nm}$ & $\mathrm{nm}$ & $\mathrm{nm}$ & $\mathrm{nm}$ & 0.306 & 0.477 & $\mathrm{~nm}$ & 0.808 & 0.732 & 0.58 & 0.232 & $\mathrm{~nm}$ & $\mathrm{~nm}$ \\
\hline acetone $^{\mathrm{a}}$ & 0.429 & 0.525 & 0.645 & 0.673 & 0.235 & 0.506 & 0.803 & 0.694 & 0.590 & 0.57 & 0.167 & $\mathrm{~nm}$ & $\mathrm{~nm}$ \\
\hline propanal $^{\mathrm{a}}$ & 0.067 & 0.082 & 0.101 & 0.105 & 0.037 & 0.079 & 0.126 & 0.109 & 0.092 & 0.09 & 0.026 & $\mathrm{~nm}$ & $\mathrm{~nm}$ \\
\hline isoprene $\mathrm{e}^{\mathrm{a}}$ & 0.236 & 0.366 & 0.402 & 0.396 & 0.271 & 0.296 & 0.625 & 0.378 & 0.386 & 0.37 & 0.112 & $\mathrm{~nm}$ & $\mathrm{~nm}$ \\
\hline furan $^{\mathrm{a}}$ & 0.207 & 0.320 & 0.352 & 0.347 & 0.237 & 0.259 & 0.547 & 0.331 & 0.338 & 0.33 & 0.098 & $\mathrm{~nm}$ & $\mathrm{~nm}$ \\
\hline methylvinyl ketone $\mathrm{a}^{\mathrm{a}}$ & 0.166 & 0.499 & 0.340 & $\mathrm{~nm}$ & 0.399 & 0.318 & 0.215 & 0.411 & 0.436 & 0.35 & 0.113 & $\mathrm{~nm}$ & $\mathrm{~nm}$ \\
\hline methacrolein ${ }^{\mathrm{a}}$ & 0.066 & 0.198 & 0.135 & $\mathrm{~nm}$ & 0.158 & 0.126 & 0.085 & 0.163 & 0.173 & 0.14 & 0.045 & $\mathrm{~nm}$ & $\mathrm{~nm}$ \\
\hline crotonaldehyde $\mathrm{a}^{\mathrm{a}}$ & 0.100 & 0.302 & 0.205 & $\mathrm{~nm}$ & 0.241 & 0.192 & 0.130 & 0.248 & 0.263 & 0.21 & 0.068 & $\mathrm{~nm}$ & $\mathrm{~nm}$ \\
\hline methylethyl ketone $\mathrm{e}^{\mathrm{a}}$ & 0.229 & 0.469 & $\mathrm{~nm}$ & $\mathrm{~nm}$ & $\mathrm{~nm}$ & $\mathrm{~nm}$ & 0.654 & $\mathrm{~nm}$ & $\mathrm{~nm}$ & 0.45 & 0.213 & $\mathrm{~nm}$ & $\mathrm{~nm}$ \\
\hline methyl propanal ${ }^{\mathrm{a}}$ & 0.081 & 0.165 & $\mathrm{~nm}$ & $\mathrm{~nm}$ & $\mathrm{~nm}$ & $\mathrm{~nm}$ & 0.230 & $\mathrm{~nm}$ & $\mathrm{~nm}$ & 0.16 & 0.075 & $\mathrm{~nm}$ & $\mathrm{~nm}$ \\
\hline acetol and methylacetate & $\mathrm{nm}$ & $\mathrm{nm}$ & 0.649 & $\mathrm{~nm}$ & 0.840 & 0.607 & 0.895 & 0.700 & 0.627 & 0.72 & 0.120 & $\mathrm{~nm}$ & $\mathrm{~nm}$ \\
\hline benzene $\mathrm{a}^{\mathrm{a}}$ & 0.189 & 0.381 & 0.168 & $\mathrm{~nm}$ & 0.538 & 0.176 & 0.234 & 0.261 & 0.172 & 0.26 & 0.131 & $\mathrm{~nm}$ & $\mathrm{~nm}$ \\
\hline $\mathrm{C}_{6}$ carbonyls & 0.098 & 0.307 & 0.105 & $\mathrm{~nm}$ & $\mathrm{Nm}$ & $\mathrm{nm}$ & 0.241 & 0.363 & 0.159 & 0.21 & 0.109 & $\mathrm{~nm}$ & $\mathrm{~nm}$ \\
\hline 3-methylfuran ${ }^{\mathrm{a}}$ & 0.252 & 0.707 & 0.434 & $\mathrm{~nm}$ & 0.843 & 0.389 & 0.668 & 0.511 & 0.413 & 0.53 & 0.196 & $\mathrm{~nm}$ & $\mathrm{~nm}$ \\
\hline 2-methylfuran ${ }^{\mathrm{a}}$ & 0.036 & 0.101 & 0.062 & $\mathrm{~nm}$ & 0.120 & 0.056 & 0.095 & 0.073 & 0.059 & 0.08 & 0.028 & $\mathrm{~nm}$ & $\mathrm{~nm}$ \\
\hline hexanal $^{\mathrm{a}}$ & 0.006 & 0.017 & 0.010 & $\mathrm{~nm}$ & 0.020 & 0.009 & 0.016 & 0.012 & 0.010 & 0.01 & 0.005 & $\mathrm{~nm}$ & $\mathrm{~nm}$ \\
\hline 2,3 butanedione $^{\mathrm{a}}$ & 0.317 & 0.790 & 0.509 & $\mathrm{~nm}$ & 0.855 & 0.490 & 0.995 & 0.634 & 0.659 & 0.66 & 0.219 & $\mathrm{~nm}$ & $\mathrm{~nm}$ \\
\hline 2-pentanone $\mathrm{a}^{\mathrm{a}}$ & 0.032 & 0.085 & 0.052 & $\mathrm{~nm}$ & 0.094 & 0.051 & 0.106 & 0.066 & 0.069 & 0.07 & 0.024 & $\mathrm{~nm}$ & $\mathrm{~nm}$ \\
\hline 3-pentanone $\mathrm{e}^{\mathrm{a}}$ & 0.014 & 0.038 & 0.023 & $\mathrm{~nm}$ & 0.042 & 0.023 & 0.047 & 0.029 & 0.031 & 0.03 & 0.011 & $\mathrm{~nm}$ & $\mathrm{~nm}$ \\
\hline toluene & 0.102 & 0.109 & 0.126 & $\mathrm{~nm}$ & 0.227 & 0.096 & 0.399 & 0.135 & 0.368 & 0.20 & 0.123 & $\mathrm{~nm}$ & $\mathrm{~nm}$ \\
\hline phenol $^{\mathrm{a}}$ & $\mathrm{nm}$ & $\mathrm{nm}$ & $\mathrm{nm}$ & $\mathrm{nm}$ & $\mathrm{nm}$ & $\mathrm{nm}$ & $\mathrm{nm}$ & 0.406 & 0.282 & 0.34 & 0.088 & $\mathrm{~nm}$ & $\mathrm{~nm}$ \\
\hline other substituted furans & $\mathrm{nm}$ & $\mathrm{nm}$ & $\mathrm{nm}$ & $\mathrm{nm}$ & $\mathrm{nm}$ & $\mathrm{nm}$ & $\mathrm{nm}$ & 1.095 & 1.071 & 1.08 & 0.016 & $\mathrm{~nm}$ & $\mathrm{~nm}$ \\
\hline furaldehydes & $\mathrm{nm}$ & $\mathrm{nm}$ & $\mathrm{nm}$ & $\mathrm{nm}$ & $\mathrm{nm}$ & $\mathrm{nm}$ & $\mathrm{nm}$ & 0.255 & 0.256 & 0.26 & 0.001 & $\mathrm{~nm}$ & $\mathrm{~nm}$ \\
\hline xylenes $^{\mathrm{a}}$ & 0.086 & 0.092 & 0.076 & $\mathrm{~nm}$ & 0.132 & 0.060 & 0.322 & 0.137 & 0.115 & 0.13 & 0.083 & $\mathrm{~nm}$ & $\mathrm{~nm}$ \\
\hline ethylbenzene ${ }^{a}$ & 0.053 & 0.084 & 0.047 & $\mathrm{~nm}$ & 0.118 & 0.044 & 0.126 & 0.078 & 0.052 & 0.08 & 0.033 & $\mathrm{~nm}$ & $\mathrm{~nm}$ \\
\hline $\mathrm{PM}_{10}$ & 17.61 & 14.43 & 17.94 & 20.18 & 19.81 & 17.27 & 26.41 & 12.53 & 14.28 & 17.83 & 4.121 & $\mathrm{~nm}$ & $\mathrm{~nm}$ \\
\hline \multicolumn{14}{|l|}{ UCI-Canister species } \\
\hline OCS & $\mathrm{nm}$ & $\mathrm{nm}$ & $\mathrm{nm}$ & $\mathrm{nm}$ & $\mathrm{nm}$ & $\mathrm{nm}$ & $\mathrm{nm}$ & 0.0247 & $\mathrm{~nm}$ & 0.0247 & $\mathrm{~nm}$ & $\mathrm{~nm}$ & $\mathrm{~nm}$ \\
\hline DMS & $\mathrm{nm}$ & $\mathrm{nm}$ & $\mathrm{nm}$ & $\mathrm{nm}$ & $\mathrm{nm}$ & $\mathrm{nm}$ & $\mathrm{nm}$ & 0.0022 & $\mathrm{~nm}$ & 0.0022 & $\mathrm{~nm}$ & $\mathrm{~nm}$ & $\mathrm{~nm}$ \\
\hline CFC 12 & $\mathrm{~nm}$ & $\mathrm{~nm}$ & $\mathrm{~nm}$ & $\mathrm{~nm}$ & $\mathrm{~nm}$ & $\mathrm{~nm}$ & $\mathrm{~nm}$ & 0.0028 & $\mathrm{~nm}$ & 0.0028 & $\mathrm{~nm}$ & $\mathrm{~nm}$ & $\mathrm{~nm}$ \\
\hline $\mathrm{MeONO}_{2}$ & $\mathrm{~nm}$ & $\mathrm{~nm}$ & $\mathrm{~nm}$ & $\mathrm{~nm}$ & $\mathrm{~nm}$ & $\mathrm{~nm}$ & $\mathrm{~nm}$ & 0.0163 & $\mathrm{~nm}$ & 0.0163 & $\mathrm{~nm}$ & $\mathrm{~nm}$ & $\mathrm{~nm}$ \\
\hline $\mathrm{EtONO}_{2}$ & $\mathrm{~nm}$ & $\mathrm{~nm}$ & $\mathrm{~nm}$ & $\mathrm{~nm}$ & $\mathrm{~nm}$ & $\mathrm{~nm}$ & $\mathrm{~nm}$ & 0.0057 & $\mathrm{~nm}$ & 0.0057 & $\mathrm{~nm}$ & $\mathrm{~nm}$ & $\mathrm{~nm}$ \\
\hline $\mathrm{i}-\mathrm{PrONO}_{2}$ & $\mathrm{~nm}$ & $\mathrm{~nm}$ & $\mathrm{~nm}$ & $\mathrm{~nm}$ & $\mathrm{~nm}$ & $\mathrm{~nm}$ & $\mathrm{~nm}$ & 0.0010 & $\mathrm{~nm}$ & 0.0010 & $\mathrm{~nm}$ & $\mathrm{~nm}$ & $\mathrm{~nm}$ \\
\hline $\mathrm{n}-\mathrm{PrONO}_{2}$ & $\mathrm{~nm}$ & $\mathrm{~nm}$ & $\mathrm{~nm}$ & $\mathrm{~nm}$ & $\mathrm{~nm}$ & $\mathrm{~nm}$ & $\mathrm{~nm}$ & 0.0003 & $\mathrm{~nm}$ & 0.0003 & $\mathrm{~nm}$ & $\mathrm{~nm}$ & $\mathrm{~nm}$ \\
\hline $2-\mathrm{BuONO}_{2}$ & $\mathrm{~nm}$ & $\mathrm{~nm}$ & $\mathrm{~nm}$ & $\mathrm{~nm}$ & $\mathrm{~nm}$ & $\mathrm{~nm}$ & $\mathrm{~nm}$ & 0.0006 & $\mathrm{~nm}$ & 0.0006 & $\mathrm{~nm}$ & $\mathrm{~nm}$ & $\mathrm{~nm}$ \\
\hline $\mathrm{C}_{2} \mathrm{H}_{6}$ & $\mathrm{~nm}$ & $\mathrm{~nm}$ & $\mathrm{~nm}$ & $\mathrm{~nm}$ & $\mathrm{~nm}$ & $\mathrm{~nm}$ & $\mathrm{~nm}$ & 0.5600 & $\mathrm{~nm}$ & 0.5600 & $\mathrm{~nm}$ & $\mathrm{~nm}$ & $\mathrm{~nm}$ \\
\hline 1-Butene & $\mathrm{nm}$ & $\mathrm{nm}$ & $\mathrm{nm}$ & $\mathrm{nm}$ & $\mathrm{nm}$ & $\mathrm{nm}$ & $\mathrm{nm}$ & 0.0200 & $\mathrm{~nm}$ & 0.0200 & $\mathrm{~nm}$ & $\mathrm{~nm}$ & $\mathrm{~nm}$ \\
\hline trans-2-Butene & $\mathrm{nm}$ & $\mathrm{nm}$ & $\mathrm{nm}$ & $\mathrm{nm}$ & $\mathrm{nm}$ & $\mathrm{nm}$ & $\mathrm{nm}$ & 0.0161 & $\mathrm{~nm}$ & 0.0161 & $\mathrm{~nm}$ & $\mathrm{~nm}$ & $\mathrm{~nm}$ \\
\hline cis-2-Butene & $\mathrm{nm}$ & $\mathrm{nm}$ & $\mathrm{nm}$ & $\mathrm{nm}$ & $\mathrm{nm}$ & $\mathrm{nm}$ & $\mathrm{nm}$ & 0.0202 & $\mathrm{~nm}$ & 0.0202 & $\mathrm{~nm}$ & $\mathrm{~nm}$ & $\mathrm{~nm}$ \\
\hline
\end{tabular}

${ }^{\mathrm{a}} \mathrm{A}$ branching ratio has been applied to the signal from a single mass channel as measured by Karl et al. (2007a).

b $\mathrm{nm}$ indicates "not measured."

${ }^{\mathrm{c}}$ The mega-plume effective emission factor minus the study average emission factor given as the number of standard deviations in the study-average emission factor. 

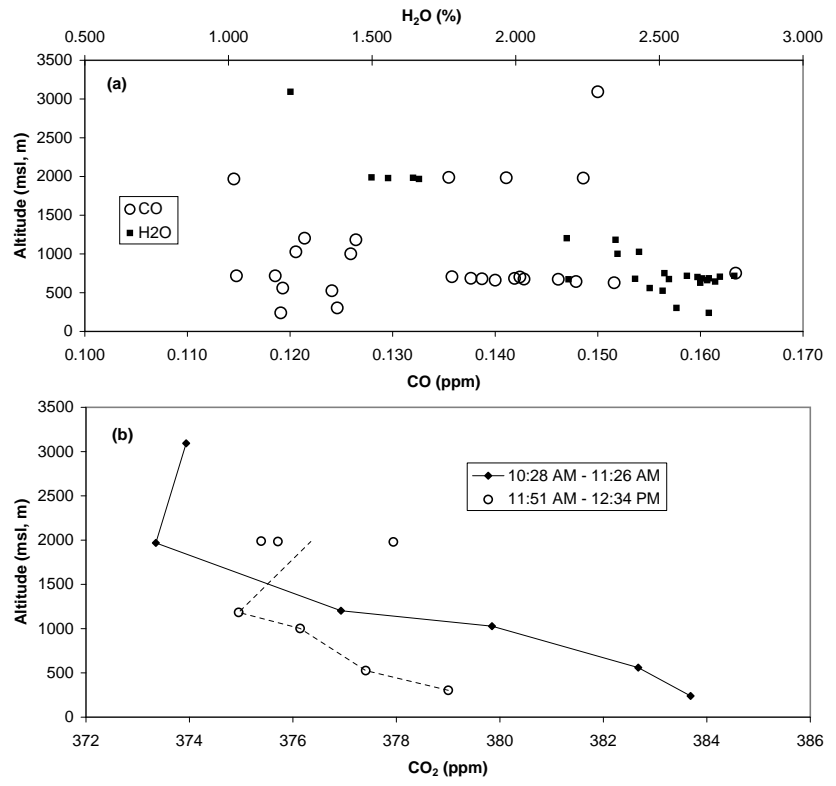

Fig. 3. Clean background air, early in the local dry season, near Manaus on 6 and 7 September, 2004. (a) CO and water from AFTIR grab samples of ambient air. Air parcels with high $\mathrm{CO}$ above the boundary layer were likely affected by transport from a biomass burning region to the southeast. (b) AFTIR vertical profiles for $\mathrm{CO}_{2}$ above the ZF-14 Tower on 6 September showing progressive depletion by photosynthesis of the $\mathrm{CO}_{2}$ that builds up overnight from respiration.

increase in pollution in the area and/or the fact that our measurements occurred part way into the beginning of the dry season so that there were probably small enhancements from biomass burning. (A few fires were sampled around noon on 7 September.) Figure 3 a also shows the water mixing ratios. The higher altitude $\mathrm{CO}$ samples are from above the mixed layer and they show some of the higher mixing ratios. This is consistent with HYSPLIT back-trajectories (Draxler and Rolph, 2003) indicating that the air at this altitude was transported from a region to the southeast with much active burning as suggested by numerous NOAA-12 hotspots. In contrast, HYSPLIT back-trajectories show that the mixed layer air came from the northeast, which was a region mostly free of hotspots.

Figure $3 \mathrm{~b}$ shows two $\mathrm{CO}_{2}$ vertical profiles above the ZF14 Tower northeast of Manaus. One is from late morning and the other is from midday. The profiles are consistent with the $\mathrm{CO}_{2}$ profiles observed by Chou et al. (2002) in the same region. The morning profiles show $\mathrm{CO}_{2}$ enhancements at lower altitudes due to nighttime respiration exceeding photosynthesis and, as the day progresses, the enhancements decrease as the forest "draws down" $\mathrm{CO}_{2}$. Chou et al. (2002) actually observed a $\mathrm{CO}_{2}$ deficit at lower altitudes by afternoon, but we did not measure afternoon vertical profiles. Our higher altitude $\mathrm{CO}_{2}$ shows small increases in the later pro-

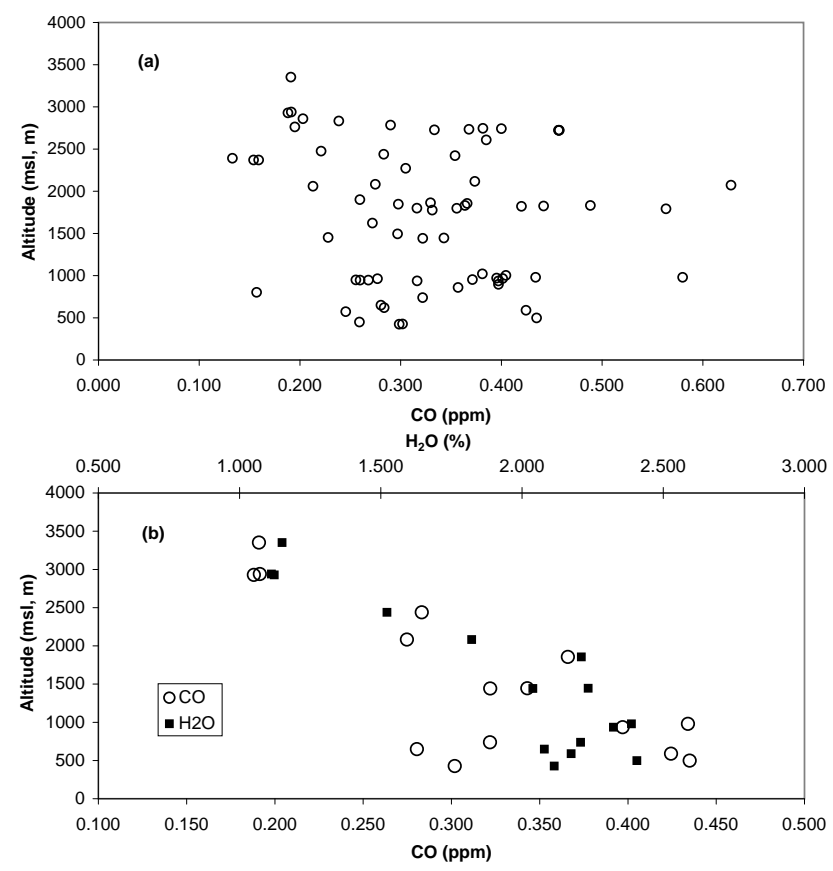

Fig. 4. Regional haze due to biomass fires late in the dry season near Alta Floresta. (a) CO from AFTIR grab samples of ambient air vs altitude for 29 August-5 September. (b) as in a for $\mathrm{CO}$ and $\mathrm{H}_{2} \mathrm{O}$ for 30 and 31 August only, illustrating efficient, initial trapping of the fire-caused haze in the mixed (boundary) layer. (The water vertical profiles can be obtained in other units from the authors.)

file, which could also be consistent with some transport of biomass burning emissions in the upper layer. The main difference between Chou et al. (2002) and our current measurements is the obvious effect of increasing global $\mathrm{CO}_{2}$. Their $1987 \mathrm{CO}_{2}$ values average around $350 \mathrm{ppm}$, while our 2004 average for the same region is around $380 \mathrm{ppm}$. Above the $\mathrm{ZF}-14$ tower, our $\mathrm{PM}_{10}$ ranged from $\sim 40 \mu \mathrm{g} \mathrm{m}^{-3}$ near the surface to $\sim 30 \mu \mathrm{g} \mathrm{m}^{-3}$ near the top of the mixed layer. Our $\mathrm{O}_{3}$ ranged from 1-10 ppbv near the surface and increased to 20-30 ppbv near the top of the profiles. Our $\mathrm{O}_{3}$ profile is similar to that of Chou et al. (2002).

\subsection{Characteristics of aged regional smoke haze}

In contrast to the region near Manaus, the region near Alta Floresta was well into the local dry season and heavily impacted by numerous fires that caused a regional haze of aged smoke sequestered in the mixed layer. (The fire emission factors in Table 2 are derived only from smoke $<$ a few minutes old that was sampled in concentrated, visually-obvious plumes and not from smoke of unknown age that constitutes the regional haze layer.) Figure 4a shows all the CO values from AFTIR grab samples that were not in smoke plumes in this region. The range is from $100-600 \mathrm{ppb}$ with an average and standard deviation of $328 \pm 102 \mathrm{ppb}$. Thus 
the background, mixed-layer air in this large fire-impacted region had about 2.5 times as much $\mathrm{CO}$ as was found near Manaus. This degree of impact is similar to the impact on dry season $\mathrm{CO}$ observations at the same latitude in Africa (Fig. 1b of Yokelson et al., 2003a).

Most of the lower $\mathrm{CO}$ values were observed above the mixed layer as can be seen more easily in Fig. 4b. Figure $4 b$ shows the $\mathrm{CO}$ and water AFTIR grab sample data in background air for 30 and 31 August. On these days we spent relatively more time above the boundary layer so the vertical patterns are more apparent. The water and $\mathrm{CO}$ mixing ratios dropped off with altitude in remarkable correlation. This is consistent with our visual observation that the plumes from active fires rarely penetrated the top of the mixed layer; a limitation that was also observed during the southern African biomass burning season (Yokelson et al., 2003a). Interestingly, the smoky mixed layers in Brazil in 2004 extended to only $2-3 \mathrm{~km}$ altitude; much lower than the $5-6 \mathrm{~km}$ altitude observed at the same latitude, time-of-year, and local timeof-day in Africa during 2000 (Yokelson et al., 2003a (Fig. 1); Schmid et al., 2003 (Fig. 11)).

We can compare our airborne $\mathrm{CO}$ observations in the 2004 regional smoke/haze to a long record of previous airborne measurements in Brazil. In 1979 and 1980 Crutzen et al. (1985) measured CO from 100-400 ppb in haze layers over the Amazon (their Figs. 10 and 11). The 1985 study of Andreae et al. (1988) shows Amazon dry season CO ranging from 150-600 ppb (their Fig. 4). Kaufman et al. (1992) also reported haze layer $\mathrm{CO}$ ranging from $\sim 150-600 \mathrm{ppb}$ in 1989 (their Fig. 4). Blake et al. (1996) observed haze layer CO values from $\sim 100-400$ during TRACE A in 1992. In 1995 biomass burning was well above average in Brazil. The SCAR-B mission was conducted late in the 1995 dry season as biomass burning peaked and Reid et al. (1998) observed much higher levels of $\mathrm{CO}$ than we have presented thus far. Average $\mathrm{CO}$ values for flights based in several central Brazil locations ranged from 440-760 ppb (their Table 1).

Our average $\mathrm{PM}_{10}$ values for vertical profiles in the regional haze layer ranged from $70-120 \mu \mathrm{g} / \mathrm{m}^{3}$ at $300-500 \mathrm{~m}$ to $30-60 \mu \mathrm{g} / \mathrm{m}^{3}$ near the top $(\sim 3000 \mathrm{~m})$; similar to observations in previous years (Pereira et al., 1996; Reid et al., 1998). Ozone values were about $30 \mathrm{ppbv}$ throughout these haze layers similar to the observations in the CITE-3, Brushfire, and ABLE-2A studies referred to above. During SCAR$\mathrm{B}$, however, $\mathrm{O}_{3}$ ranged from $60-100 \mathrm{ppb}$, consistent with the more polluted boundary layer present in the late 1995 dry season.

In summary, 2004, through 7 September, had a typical amount of biomass burning haze based on the comparison of our $\mathrm{CO}, \mathrm{PM}_{10}$, and $\mathrm{O}_{3}$ measurements to other measurements from the last 30 years. However, as discussed in Sect. 3.4, our measurements on 8 September probed widespread, unusually high levels of pollutants.

It is also of interest to compare the airborne $\mathrm{CO}$ data with the $\mathrm{CO}$ data obtained during the same time period by the ground-based FTIR system (Christian et al., 2007b). The ground-based samples obtained well away from visible smoke plumes return much higher $\mathrm{CO}$ values. The average for 25 afternoon samples taken within $\sim 100 \mathrm{~km}$ of Alta Floresta from 26 August-8 September was $1.35 \pm 1.15 \mathrm{ppm}$ with a range from 0.330 to $4.76 \mathrm{ppm}$. Gatti et al. (personal communication) monitored $\mathrm{CO}$ levels at a pasture site in Rondonia in September and October of 1999 and observed a range of $\mathrm{CO}$ from 0.6 to $1.3 \mathrm{ppm}$. Thus while airborne sampling retrieved the composition of the majority of the mixed layer, more polluted air was found at ground level than would be inferred from airborne measurements. At this time we don't know the thickness of the ground-level layer. Above the mixed layer, the CO tends to drop off sharply to a mixing ratio characteristic of the free troposphere. The African and the Brazilian $\mathrm{CO}$ vertical profiles are not shaped like the apriori CO vertical profile used for MOPITT CO retrievals (Emmons et al., 2004). We speculate that consideration of the actual profile shapes might enhance $\mathrm{CO}$ retrievals from space-based instruments.

\subsection{Initial emissions from tropical deforestation fires}

Since a variety of large changes can occur in smoke chemistry in the minutes to days after emission, segregation of results by sample age and history (to the degree possible) enhances interpretation of the results and comparison with models and other measurements. Thus, only excess mixing ratios measured $<\sim 1 \mathrm{~km}$ from the fire were used to compute our initial emission ratios and emission factors. Forty-two plume penetrations of this type were made. In contrast to the background-air grab samples discussed above, the excess $\mathrm{CO}$ mixing ratios (above background) in the AFTIR, plume grab samples were in the range $1-31$ ppmv for $\sim 90 \%$ of the samples. Thus, excellent signal to noise was observed on all instruments for each fire for numerous species.

The fire-average, initial emission factors for each compound and fire, along with the fire average MCE, are listed in Table 2. Because $\mathrm{NO}$ is rapidly converted to $\mathrm{NO}_{2}$ (largely due to reaction with $\mathrm{O}_{3}$ in the entrained background air), we also report a single EF for " $\mathrm{NO}_{\mathrm{x}}$ as $\mathrm{NO}$ ". We computed this $\mathrm{EF}$ from the $\mathrm{NO}_{\mathrm{x}} / \mathrm{CO}_{2}$ molar ER obtained as described in Sect. 2.2.1, but it can also be estimated from Table 2 data using: EFNO+(30/46) $\times \mathrm{EFNO}_{2}$. If desired, the molar ER for each fire can be derived from the EF in Table 2 after accounting for any difference in molecular mass.

The timing and extent, and perhaps representativeness, of Brazilian biomass burning in 2004 can be compared to other years using metrics other than the regional $\mathrm{CO}, \mathrm{PM}$, and $\mathrm{O}_{3}$ values discussed in Sect. 3.2. Dating back to at least 1993 a near-continuous, regional record of aerosol optical thickness (Holben et al., 1996; Echalar et al., 1998; http://aeronet. gsfc.nasa.gov/newaeronet1.html) and deforestation rates exists. Unfortunately, the Alta Floresta sun photometer was not operational during the peak of the 2004 burning season 
(B. Holben, personal communication). The INPE deforestation data, however, shows $2004\left(27429 \mathrm{~km}^{2}\right)$ as the second highest year after $1995\left(29059 \mathrm{~km}^{2}\right)$ - the year of the SCARB campaign. Thus, both TROFFEE and SCAR-B were conducted in years when the deforested area was well above the long-term average of $\sim 20000 \mathrm{~km}^{2}$. The number of NOAA12 hotspots (http://www.cptec.inpe.br/queimadas/) for 2004 (236821) is above the 2000-2005 average of 192569 and just above 2002 (232921), which was the second-biggest year since 2000. Interestingly, 2002 was the year for another smoke-sampling campaign termed SMOCC (Andreae et al., 2004). While the annual totals for the NOAA-12 hotspots are readily available, they likely underestimate the true number of fires, especially under extreme burning conditions as discussed in Sect. 3.4. In summary, most of our fire sampling was probably conducted under "average" conditions as shown in Sect. 3.2, however, the 2004 annual burning was above average because of intense burning beginning $\sim 7-8$ September, which was towards the end of our campaign.

\subsubsection{Natural variation in emission factors}

In Fig. 5 we plot the fire-average emission factors versus MCE (data from Table 2) for selected compounds. This gives some idea of the natural variation in emission factors that results from deforestation fires burning under a range of vegetative/environmental conditions and with different mixtures of flaming and smoldering combustion. Figure 5a shows $\mathrm{NO}_{\mathrm{x}}$ emissions which increase as MCE (and thus flaming combustion) increases. Figures $5 \mathrm{~b}-\mathrm{d}$ show the pattern typical of most of the VOC we measured - the EF for these "smoldering compounds" increased with decreasing MCE. Figure 5e shows that EFPM 10 also increases with decreasing MCE. The range in EF (with MCE) for these species is about a factor of two, which is a smaller range than we observed for African savanna fires (Yokelson et al., 2003a). Figure $5 \mathrm{f}$ shows that $\mathrm{EFCH}_{3} \mathrm{CN}$ did not have a strong dependence on MCE. This is similar to the pattern observed for HCN from savanna fires by Yokelson et al. (2003a). However, like $\mathrm{EFHCN}$, the $\mathrm{EFCH}_{3} \mathrm{CN}$ did vary by $\sim \pm 50 \%$, possibly due to varying fuel $\mathrm{N}$ content. The use of acetonitrile as a biomass burning indicator/tracer is discussed later in this paper and by Karl et al. (2007a).

\subsubsection{Comparison with other work}

It is most meaningful to compare our study-average, initial emission-factor measurements in nascent smoke from Brazilian deforestation fires with measurements made in AugustSeptember of 1990 using a tower-based platform by Ward et al. (1992) during BASE-B; and in August-September of 1995 from an aircraft by Ferek et al. (1998) as part of SCARB. We also compare to a widely-used compilation of EF for tropical forests by Andreae and Merlet (2001).
The $\mathrm{EFCO}_{2}, \mathrm{EFCO}$, and, especially, MCE all reflect the overall mix of flaming and smoldering combustion in a fire and thus these parameters can give some idea of the similarity of the combustion characteristics of the fires we sampled to fires sampled previously. This serves as one probe of how representative our fires were of regional fires in general. Ward et al. and Ferek et al. report individual values for flaming and smoldering combustion and it is not always clear if they have a recommended study-average for primary forest fuels. However, our study-average MCE for deforestation fires (Table 2) indicates that they burn with roughly equal amounts of flaming and smoldering (Yokelson et al., 1996). Thus, when necessary, we compare to the average of the flaming and smoldering values given in the other work in the following discussion.

For $\mathrm{CO}_{2}$ the $\mathrm{EF}$ are $1614 \pm 56$ (Ward et al., 1992), 1599

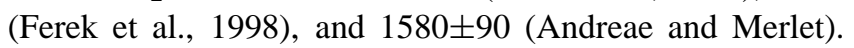
All these values are reasonably close to each other and our study average of $1615 \pm 40$. Similarly for CO the previous values are $110 \pm 28,105$, and $104 \pm 20$ in excellent agreement with each other and our value of $101 \pm 24$. The MCE are $0.903 \pm 0.03,0.906,0.906$, and our value of $0.910 \pm 0.021$. Thus our values are well within the range of previous measurements, but seem to reflect slightly more flaming combustion on average than previous work.

The research fire on 5 September, which was designed to simulate regional fires apparently had a significantly higher MCE than our regional average. However, the higher MCE partly reflected that we did sample the beginning of the fire, but could not finish sampling the full fire (smoldering contributes less at the beginning of a fire) because of aircraft fuel considerations. Our airborne samples showed that MCE initially decreased with time and then stabilized. It is also interesting to note that the fires sampled later in TROFFEE tended to have higher MCE, which could be due to the protracted dry period after unusual rains in mid August. Finally, the plume from the intense burning event sampled on 8 September (see Sect. 3.4) also had higher than study-average MCE. Thus late-season, "higher-MCE" plumes may account for a fair percentage of the total regional biomass burned. On the other hand, prolonged dry spells will desiccate large diameter logs, which tend to burn with a low MCE $(\sim 0.788$, Christian et al., 2007b) producing initially unlofted smoke. So the real nature of the "total regional smoke" is governed by complex - sometimes competing - trends, which need further analysis.

Rather than an exhaustive species by species comparison with other work for the numerous other trace gases measured, we have tried to summarize the comparison in Fig. 6 and provide some useful guidance. Then a few comments are made about select individual species. Many compounds appear in both our work (Table 2) and the recommendations of Andreae and Merlet (AM). In general, our values are based on a larger number of measurements and should probably be preferred to those in AM who acknowledge basing many 

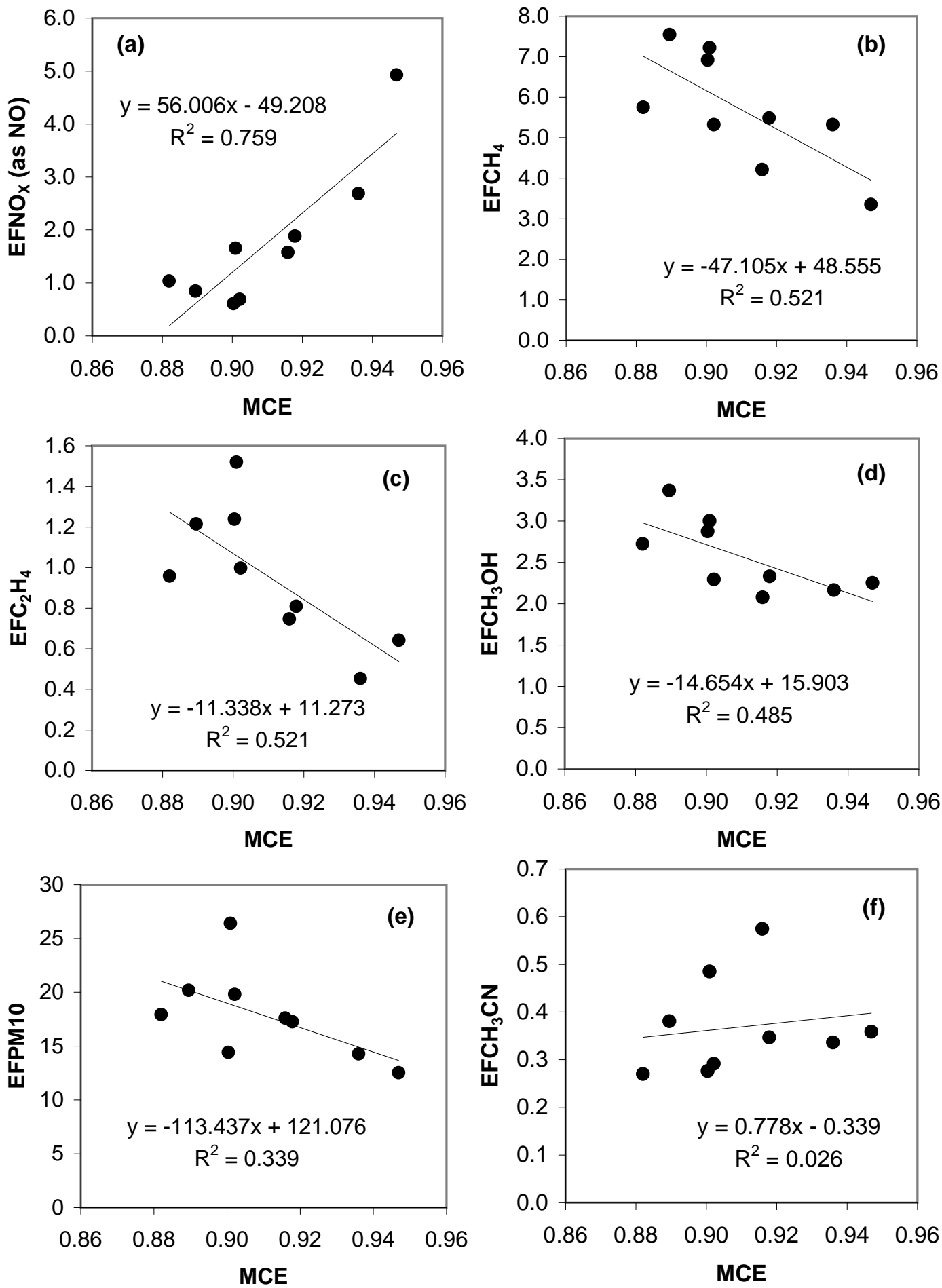

Fig. 5. Fire-average emission factors (EF) plotted versus fire-average modified combustion efficiency (MCE) for the indicated species (data from Table 2). (See discussion in Sect. 3.3.1).

of their values on 1-2 less direct measurements and/or "best guesses" due to a lack of detailed information available at the time. On the other hand, a number of compounds appear in the AM recommendations that we did not measure during TROFFEE. Most of these are minor plume constituents, but some are of major importance (e.g. $\mathrm{SO}_{2}$ ). We recommend 

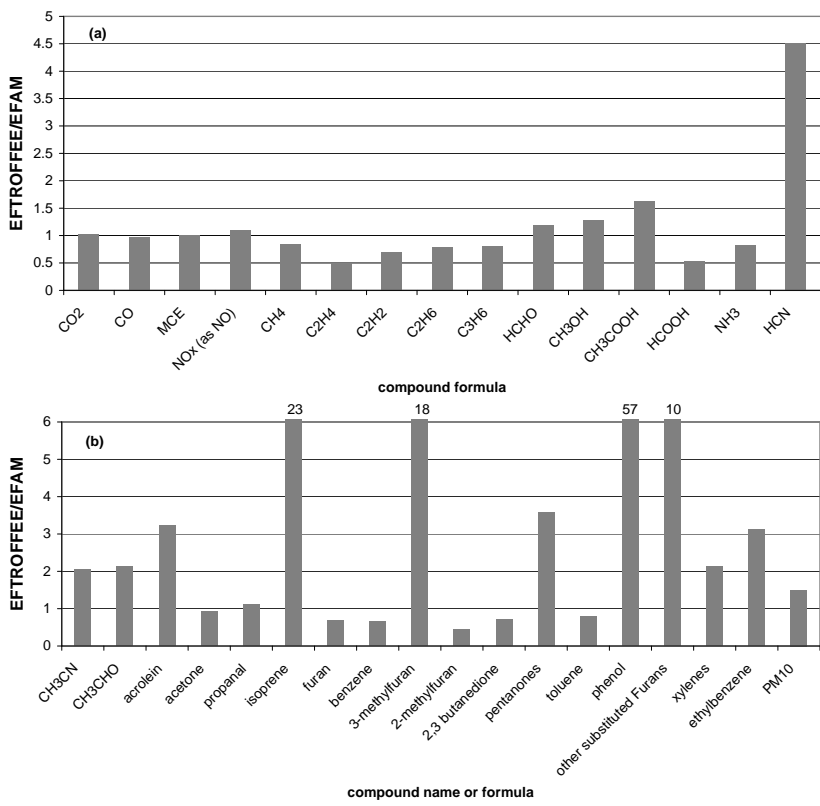

Fig. 6. Comparison of the TROFFEE airborne study emission factors with the recommendations of Andrea and Merlet (2001) (AM) for species in both studies. ( $\mathrm{AM} \mathrm{PM}_{10}$ is taken as $1.3 \times \mathrm{AM} \mathrm{PM}_{2.5}$.) With 8 exceptions, the older (AM) recommendations are within a factor of $\sim 2$ of the newer TROFFEE EF, which are usually based on more measurements. This suggests that the AM recommendations for species not measured in TROFFEE (e.g. $\mathrm{SO}_{2}$ ) are reasonable. (a) species measured by AFTIR. (b) species measured by PTR-MS and the nephelometer. (When the ratio exceeds the scale shown the value of the ratio is given above the bar.)

using the AM values for compounds we did not measure since there is reasonable agreement between our work and theirs on most of the compounds we both address (see Fig. 6). Finally our work includes data on a number of "new," significant plume constituents for which information was not previously available. Included in this category are HONO, acrylonitrile, pyrrole, methylvinylketone, methacrolein, crotonaldehyde, methylethylketone, methylpropanal, "acetol plus methylacetate," furaldehydes, dimethylsulfide, and $\mathrm{C}_{1}-\mathrm{C}_{4}$ alkyl nitrates (Table 2).

In early fire research it was usually assumed that most of the NMOC were NMHC as was actually the case for industrial combustion of fossil fuels. As mentioned in the introduction, a key discovery of previous FTIR and PTR-MS work was that OVOC accounted for the large majority of NMOC emitted by the fires sampled. A goal of this project was to verify this for tropical deforestation fires. The TROFFEE data show that the molar ratio OVOC/NMHC is about $4: 1-$ or that OVOC account for $\sim 80 \%$ of the NMOC. With the completion of TROFFEE, there are now reasonably comprehensive field measurements of the NMOC emitted by all the major types of biomass burning. The new information provided on the "universal dominance" of OVOC is significant because of the huge size of the biomass burning source and the reactive nature of OVOC (Mason et al., 2001; Trentmann et al., 2005).

A few comments are made about individual species we measured. An IR signal due to HONO was observed on the lab fires and 2 field fires, but the measurements are semiquantitative due to a low SNR. However, the presence of any HONO signal is significant since even a small amount of $\mathrm{HONO}$ in the initial emissions is a source of $\mathrm{OH}$ that speeds up the initial plume chemistry (Trentmann et al., 2005). Our field, study-average HONO EF $(0.26 \pm 0.13 \mathrm{~g} / \mathrm{kg})$ overlaps the other relevant HONO EF we know of (Keene et al., 2006): $0.24 \mathrm{~g} / \mathrm{kg}$ shrubs, $0.19 \pm 0.08 \mathrm{~g} / \mathrm{kg}$ branches, and $0.14 \pm 0.05 \mathrm{~g} / \mathrm{kg}$ grass.

As mentioned above, the EF for acetonitrile was not strongly correlated with MCE in our field study. Thus, our study-average EF of $0.37 \pm 0.10 \mathrm{~g} / \mathrm{kg}$ seems to be a good estimate for all tropical deforestation fires regardless of MCE. However, our EF for acetonitrile from deforestation fires does differ significantly from recommended $\mathrm{EFCH}_{3} \mathrm{CN}$ for other types of burning (e.g. $0.13 \mathrm{~g} / \mathrm{kg}$ for savanna fires and $4.91 \mathrm{~g} / \mathrm{kg}$ for burning Indonesian peat (Christian et al., 2003)). In addition, acetonitrile emissions have not been measured for cooking fires, which may be the second largest type of biomass burning. Still, these results suggest that (with attention to the type of fire) PTR-MS acetonitrile measurements could contribute to source apportionment or estimates of the amount of biomass burned using inverse modeling.

The particle emission factors we measured during TROFFEE $\left(\mathrm{PM}_{10}, 17.8 \pm 4.1 \mathrm{~g} / \mathrm{kg}\right)$ are significantly larger than in previous work or recommendations. Ferek et al. (1998) reported a range of $\mathrm{EFPM}_{4}$ from $2-21 \mathrm{~g} / \mathrm{kg}$ and a study average of about $11 \mathrm{~g} / \mathrm{kg}$ for Brazilian deforestation fires. The tower-based measurements of Ward et al. (1992) returned values for $\mathrm{EFPM}_{2.5}$ ranging from 6.8 to $10.4 \mathrm{~g} / \mathrm{kg}$ with an average of about $9 \mathrm{~g} / \mathrm{kg}$ for forest fuels. Ferek et al speculated that their higher average and high end values were due to incomplete particle formation being probed from the tower platform. This hypothesis was supported by simultaneous tower and airborne PM measurements on the same Brazilian fires (Babbitt et al., 1996). In that experiment, the airborne $\mathrm{EFPM}_{2.5}$ averaged about $11 \mathrm{~g} / \mathrm{kg}$ while the $\mathrm{EFPM}_{2.5}$ measured on the same fires from towers averaged about $4 \mathrm{~g} / \mathrm{kg}$. In any case our study average value for $\mathrm{PM}_{10}$, which includes a wider range of particle sizes than the work referenced above, is significantly higher at $17.8 \pm 4.1 \mathrm{~g} / \mathrm{kg}$. For most types of biomass burning the $\mathrm{PM}_{10}$ values might be expected to be about $30 \%$ higher than the $\mathrm{PM}_{2.5}$ or $\mathrm{PM}_{4}$ values (AM, Ottmar, 2001). Applying this factor to the study average of Ferek et al gives a projected $\mathrm{PM}_{10}$ of about $14 \mathrm{~g} / \mathrm{kg}$ still lower than our TROFFEE value. A major reason for the rest of this discrepancy could be related to fire size and intensity. Ferek et al. noted that their largest, most intense fire in 
Brazil had a much higher $\mathrm{EFPM}_{4}$ or $\mathrm{PM}_{4} / \mathrm{CO}$ ratio than the other fires they sampled in SCAR-B. They cited their measurements on even larger more intense fires in North America, which had even higher $\mathrm{EFPM}_{4}$, and proposed that EFPM increase with fire size and combustion intensity. For example they cited $\mathrm{EFPM}_{3.5}$ from $15-25 \mathrm{~g} / \mathrm{kg}$ (implying an average $\mathrm{PM}_{10}$ of $\sim 26 \mathrm{~g} / \mathrm{kg}$ ) for large, intense North American fires (Radke et al., 1991; Hobbs, 1997). In our TROFFEE data, the lowest $\mathrm{EFPM}_{10}(12-14 \mathrm{~g} / \mathrm{kg})$ are from our smallest fires (5 and 7 September). Our largest EFPM $_{10}(26.4 \mathrm{~g} / \mathrm{kg})$ was obtained on 3 September. This plume was the largest and most intense we encountered. Thus we speculate that our larger study-average EFPM values for Brazil could be due to sampling larger, more-intense fires (on average) than in previous studies in Brazil. If correct, this raises two interesting questions: (1) what fire sizes contribute what fraction of the regional biomass burning and (2) is there a trend in fire size related to trends in land-use (Sect. 2.3.2).

A species by species comparison of the emissions for the three main types of burning (savannas, cooking, and deforestation) is beyond the scope of this paper. Here we just point out a few main characteristics of the 3 main types of burning. Cooking fire emissions occur year round and are not initially lofted. The emissions immediately impact human health (Bertschi et al., 2003a). The average MCE is about 0.91 and HCN was not observed from cooking fires. In contrast, savanna fires occur only in the dry season, burn with higher MCE $(\sim 0.94)$, and most of the emissions (including ample HCN) are lofted. Tropical deforestation fires also burn in the dry season (with MCE 0.91) and generally feature higher smoldering compound emissions per unit mass of fuel, higher fuel loadings, and more emissions per unit area than savanna fires. Specifically, the emission factors for methane, acetic acid, acetaldehyde, acetone, formaldehyde, ethane, methanol, ammonia, and acetonitrile were all 2-3 times higher for tropical deforestation fires than for savanna fires (Christian et al., 2003). Interestingly, the EF for carbon dioxide, ethylene, $\mathrm{HCN}$, formic acid, acetylene, and propylene were about the same for both fire types. This could imply some value for some of these compounds to serve as rough, global non-biofuel biomass burning tracers, but caution is needed as there are other sources of most of these species (Li et al., 2000; Shim et al., 2007). When compared to savanna fires, the $\mathrm{EF}$ for $\mathrm{CO}$ is significantly higher for tropical deforestation fires and the $\mathrm{EF}$ " $\mathrm{NO}_{\mathrm{x}}$ as NO" is significantly smaller for these fires. The NMOC are dominated by OVOC for all types of biomass burning. The smoke from outdoor fires that impacts human health and global climate/chemistry is aged. There are two dry seasons in the tropics: $\sim$ February-May in the Northern Hemisphere and $\sim$ June-October in the Southern Hemisphere. Only November-January are mostly unaffected by outdoor biomass burning emissions.

\subsubsection{Regional-global bottom-up emissions estimates}

About 2 million ha of tropical rain forest are burned in an average year in Brazil and $\sim 120 \mathrm{Mg} / \mathrm{ha}$ of fuel is consumed in these fires (Sect. 2.3.2). Thus, $\sim 2.4 \times 10^{11} \mathrm{~kg}$ of biomass are burned annually in primary deforestation fires. The last value can be multiplied by any EF in Table 2 for a bottom-up estimate of annual emissions from Brazilian tropical deforestation fires. For instance, $388 \mathrm{Tg}$ and $4 \mathrm{Tg}$ are crude estimates of the average annual $\mathrm{CO}_{2}$ and $\mathrm{PM}_{10}$ emissions from Brazilian deforestation fires. The amount of biomass burned and the total emissions for each species approximately double if pasture fires are included, although $20-50 \%$ even larger emissions than predicted by this type of estimate are warranted for several VOC to account for RSC in Brazilian pasture fires (Christian et al., 2007b). The $\sim 240 \mathrm{Tg}$ of primary forest biomass burned each year is about $20 \%$ of the total $(1330 \mathrm{Tg})$ consumed by tropical deforestation fires given by AM. This implies that other countries (Indonesia, Congo, Ivory Coast, etc.) have higher, national, deforestation rates. Assuming that the emissions from Brazilian deforestation fires are similar to those from deforestation fires elsewhere in the tropics, we can use our EF with the AM estimate of fuel consumption (above) to estimate global emissions from deforestation fires. For instance, this implies that about $2148 \mathrm{Tg}$ of $\mathrm{CO}_{2}$ and $24 \mathrm{Tg}$ of $\mathrm{PM}_{10}$ are emitted by deforestation fires globally on an annual basis. Of course it should be remembered that the emissions from any contributing region are emitted in much less than one year and that the vast majority of these species are too reactive to be well-mixed globally.

\subsection{Mega-plume}

Section 3.2 showed regional CO falling within the typical range observed in haze layers in previous years until 7 September. In contrast, on 8 September, during transit (at $\sim 2.0 \mathrm{~km}$ altitude) from Manaus to Cuiabá we encountered $\mathrm{CO}$ values as high as $1172 \mathrm{ppb}$ from about $8.3^{\circ} \mathrm{S}$ $(\sim 11: 00$ a.m. LT $)$ to $13^{\circ} \mathrm{S}(\sim 12: 30$ p.m. LT $)$ - a distance $>500 \mathrm{~km}$ (Fig. 7a). Visibility was often too low to see the ground. Thus, no fires were observed from the aircraft during this time. On 8 September there was also a sharp maximum in the daily NOAA- 12 hotspot total for Brazil (http://www.cptec.inpe.br/queimadas/) and a very large area with high TOMS Earth Probe aerosol index (AI) appeared (Figs. $7 \mathrm{~b}$ and c). These observations suggest the presence of either "extreme haze" or a massive plume formed from the combined output of numerous fires. Because many relatively short-lived fire emissions were still present (vide infra), we prefer the latter explanation and have termed this phenomenon a "mega-plume." The mega-plume or "white ocean" of smoke covered a large area in Brazil, Bolivia, and Paraguay for about one month - draining southeastward. Selected, narrated MODIS visible images of the smoke from this "event" are archived for 6 September to 8 October 

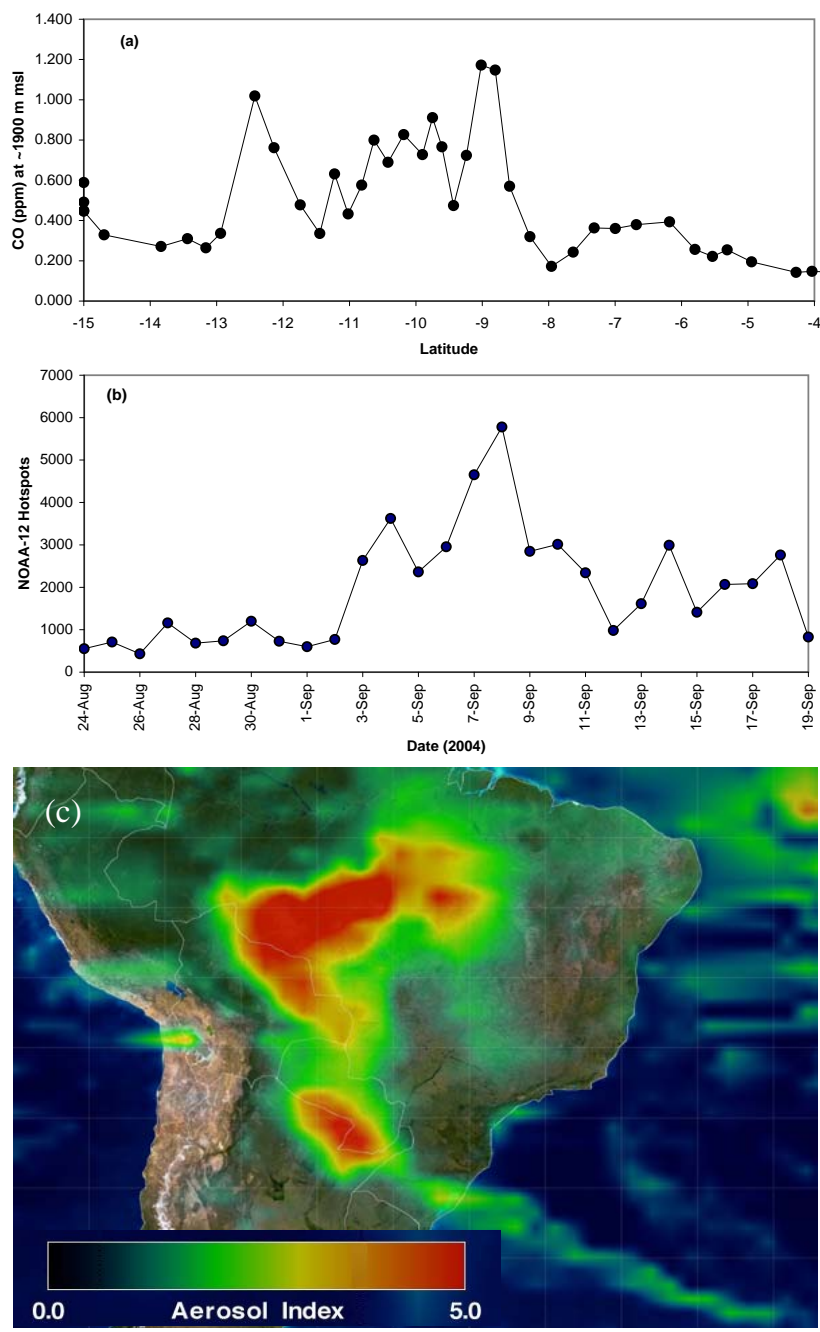

Fig. 7. The mega-plume. (a) CO vs. latitude from the 8 September, 2004 flight showing high CO extending from 8 to 13 south. (b) Daily NOAA-12 afternoon hotspots for Brazil from 24 August to 19 September, 2004. The maximum value occurs on 8 September. (c) TOMS aerosol index on 8 September, 2004.

of 2004 (http://earthobservatory.nasa.gov/NaturalHazards/ natural_hazards_v2.php3?img_id=12424) and the TOMS Earth Probe AI was elevated until late September (http:// toms.gsfc.nasa.gov/aerosols/aerosols_v8.html). The NOAA12 hotspots are elevated from $\sim 3-19$ September and the hotspots during this period account for roughly one-quarter of the total NOAA-12 hotspots for the year. This suggests that a large fraction of the total biomass burned in 2004 may have produced smoke that was processed in this megaplume/smoke-ocean event. Brown et al. (2006) describe a similar smoke event in the western Amazon occurring in the fall of 2005. Thus mega-plumes (or smoke oceans) may be fairly common in Brazil and other areas of the tropics when biomass burning is peaking. Whereas smoke plumes usually age in relative isolation from each other while diluting with regional haze, in the mega-plume scenario, direct mixing of fresh smoke plumes likely dominates. The two chemical processing environments may lead to different outcomes and the latter scenario may be the relevant processing environment for a large part of the total regional emissions.

Only the AFTIR and GPS acquired data on this flight as the other instrumentation had been deployed at the ZF-14 Tower (Karl et al., 2007b). The AFTIR spectra show that the mega-plume contained $10-50 \mathrm{ppbv}$ of numerous reactive species such as $\mathrm{NH}_{3}, \mathrm{NO}_{2}, \mathrm{CH}_{3} \mathrm{OH}$, and organic acids and high $\mathrm{PM}_{10}\left(100-200 \mu \mathrm{g} / \mathrm{m}^{3}\right)$ can be inferred from the $\mathrm{PM}_{10} / \mathrm{CO}$ ERs measured earlier. The mega-plume was not perfectly mixed, however, all the samples showed depletion (relative to $\mathrm{CO}$ ) of reactive species such as $\mathrm{HCHO}, \mathrm{C}_{2} \mathrm{H}_{4}$ and $\mathrm{C}_{2} \mathrm{H}_{2}$. Many samples also showed incipient production of $\mathrm{O}_{3}$ and both formic and acetic acids. To illustrate the megaplume chemistry and aging effects, we computed "effective emission factors" (EEF) for the mega-plume that are shown in Table 2. The last sample of clean air (at $\sim 8^{\circ} \mathrm{S}$, Fig. 7a) was used as the background for the mega-plume samples. The EEF were computed in the same way as EF (Sect. 2.2.2). However, the EEF reflect the temporary composition of the mega-plume at the unknown age that it was sampled. The EEF are not included in the computation of the study-average initial emission factors. Also shown in Table 2, for each species, is the mega-plume EEF minus the study average EF, divided by the standard deviation in the study average EF. As seen in Table 2 the average mega-plume sample was enriched by $\sim 6$ and 13 standard deviations for formic and acetic acid, respectively. This corresponds to normalized excess mixing ratios relative to $\mathrm{CO}$ of about $5 \%$ and $1.6 \%$ for these species respectively, which can be compared to the studyaverage initial values of about 1.6 and $0.3 \%$, respectively. $\Delta \mathrm{O}_{3} / \Delta \mathrm{CO}$ in the mega-plume was most often positive and ranged from -1 to $+5 \%$. Potentially similar post-emission smoke chemistry can be probed by comparing the PTR-MS data for initial emissions and the biomass-burning-induced regional haze that we sampled from 27 August to 5 September (Karl et al., 2007a). The haze was less-concentrated and of even more ambiguous age. Nevertheless, it probably had some chemical processes in common with the mega-plume. In the earlier regional haze, Karl et al. (2007a) observed a $\sim 50 \%$ increase in the acetone/acetonitrile ratio, but no evidence of secondary formation of methanol or acetaldehyde or other species.

Secondary production of ozone and organic acids in an isolated smoke plume from a forest fire was previously observed in Alaska by Goode et al. (2000). Yokelson et al. (2003a) observed $\Delta \mathrm{O}_{3} / \Delta \mathrm{CO}$ and $\Delta \mathrm{CH}_{3} \mathrm{COOH} / \Delta \mathrm{CO}$ rise to $\sim 9 \%$ in less than one hour in plumes from African grass fires, but no formic acid was produced. Jost et al. (2003) observed secondary production of acetone in a savanna fire plume. Trentmann et al. (2005) successfully modeled many aspects of the chemical evolution of individual smoke plumes in Africa, 
but could not account for the observed secondary production of acetone or acetic acid. The ozone production could only be modeled by increasing the initial VOC (to account for unmeasured VOC) or by invoking a few possible, but unconfirmed, heterogeneous effects. Our observation of fast formation of acetic acid and $\mathrm{O}_{3}$ in the mega-plume and increased acetone in the regional haze suggests that important, but unknown, chemistry occurs in isolated smoke plumes, mega-plumes, and regional haze.

It is difficult to identify what was burning to create the mega-plume, but some insight is gained from the attempt. The largest group of NOAA-12 hotspots (several thousand in number) for a late-afternoon, 8 September overpass was located near $50 \mathrm{~W}$ or $\sim 22 \mathrm{~h}$ to the east according to HYSPLIT back trajectories (Draxler and Rolph, 2003). The sampled air would have passed this location around 02:00 p.m. LT on 7 September. The afternoon overpass for 7 September shows reduced (compared to the 8th) but very substantial hotspot activity in that same area. Another, closer, large group of NOAA-12 hotspots detected on 8 September was located along $55 \mathrm{~W}$ only $\sim 4 \mathrm{~h}$ to the east. This is consistent with the observation of slight aging, but would suggest that the fires were active by 08:00-09:00 a.m. The common assumption is, however, that most fires are ignited in the afternoon. Other possibilities are that the relevant hotspots were undetected or that the HYSPLIT back trajectories are highly uncertain in this remote region. To check the former hypothesis we examined the MODIS visible archives available (but hotspot numbers not tabulated) at: http://rapidfire.sci.gsfc. nasa.gov/subsets/?AERONET_Alta_Floresta/2004252. Perhaps surprisingly, even the $\sim 10: 30$ a.m. LT Aqua overpass shows hundreds of hotspots along the $55 \mathrm{~W}$ line and $>100$ closer hotspots (not seen on NOAA-12 images) that overlap our flight track (approximately along $56 \mathrm{~W}$ ). This suggests several important things: (1) numerous fires were ignited in the morning on 8 September, (2) much of the smoke we sampled was likely $\sim 0-4 \mathrm{~h}$ old, and (3) the NOAA-12 hotspots sometimes miss significant areas of active burning (at least under extreme conditions). In any case, the megaplume samples likely probed smoke that was mostly less than 1 day old.

Christian et al. (2007b) observed a study-average MCE for RSC of $\sim .788$ in the ground-based campaign. The megaplume had a higher MCE of 0.923 suggesting that the bulk of the emissions we sampled were not produced by RSC. The mega-plume MCE is also above our study average MCE of 0.91 . This suggests that the smoke we happened to sample from this major burning episode originated from relatively more flaming combustion than in the fires we sampled earlier (except for the planned fire). The humidity during the 8 September flight was also by far the lowest we encountered. By 11:00 a.m. LT the water vapor had dropped below $1 \%$ as compared to $1.5-2.5 \%$ for afternoon lows on earlier flights. The low humidity and the higher MCE could explain the peak in the hotspots by indicating a strong preference for
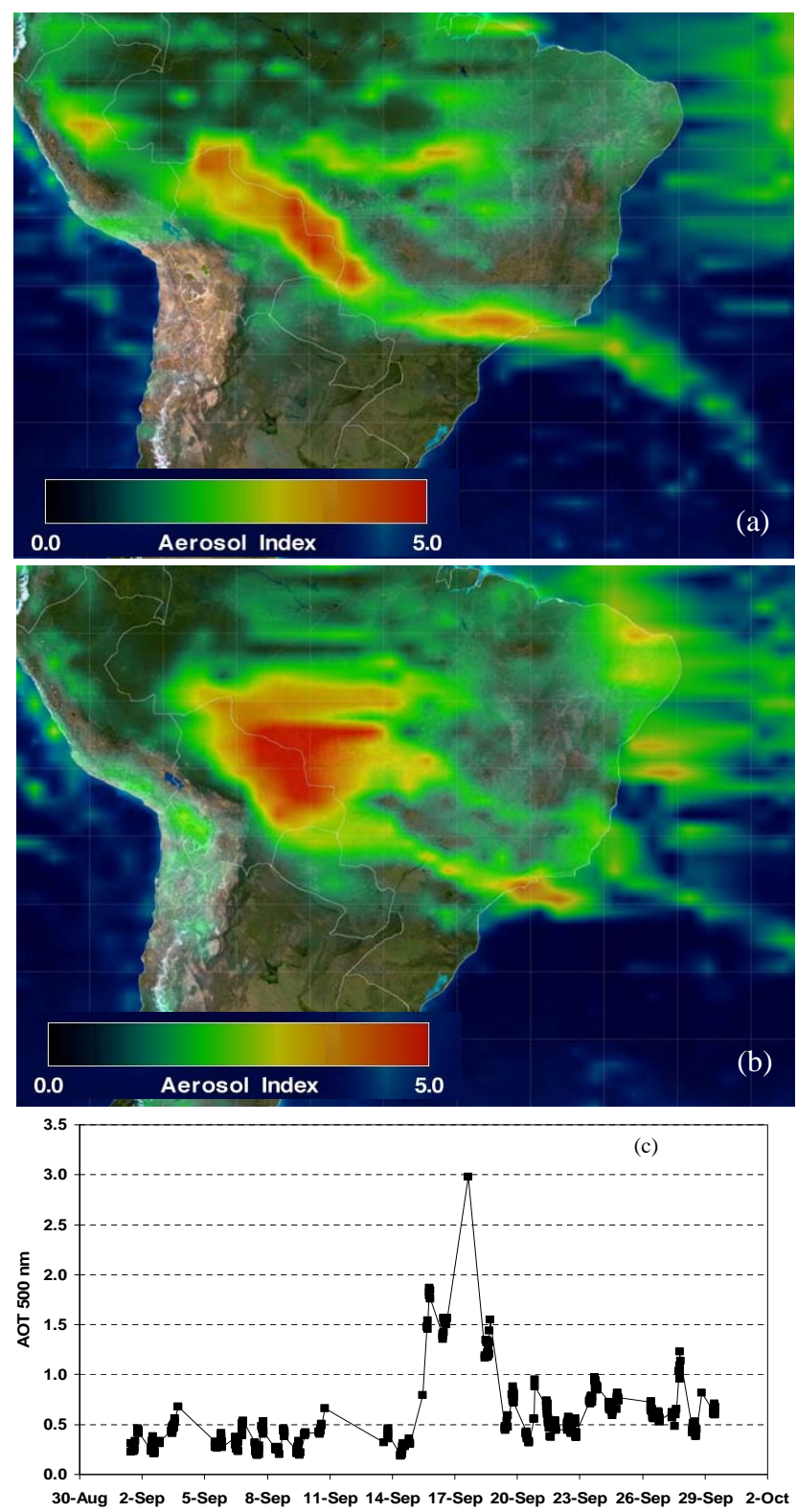

Fig. 8. (a) TOMS aerosol index (AI) on 16 September, 2004 showing concentrated biomass burning emissions (AI 3.5) approaching São Paulo. (b) TOMS AI on 17 September, 2004 showing the most concentrated emissions (AI 3.5) just past São Paulo. (c) São Paulo AERONET aerosol optical thickness for September 2004. The peak (near AOT 3) is in good absolute and temporal agreement with the TOMS AI data.

Brazilian farmers to burn under conditions that promote both flaming and high fuel consumption. In a non-technical summary; landholders wait until conditions are ideal and then do much of their annual burning in the next few days (including burning in the mornings) creating a mega-plume or "white ocean" of smoke that passes over southern Brazil and into the south Atlantic. 
There is evidence that the mega-plume had a brief, but major impact on the air quality of São Paulo, which is $\sim 1500 \mathrm{~km}$ south of the main burning region. During most of September, the mega-plume exited South America well south of São Paulo (e.g. Fig. 7c). However, the TOMS aerosol index (AI) images for 16 and 17 September show the mega-plume (with AI 3.5) exiting South America over São Paulo (Figs. 8a and b). Simultaneously, the São Paulo AERONET station recorded a factor of 3-4 increase in aerosol optical thickness above the normal, high value $(\sim 1)$ for this large urban area (Fig. 8c). This incident dramatically illustrates the amount of material transported from Amazonian fires and how long it remains in a concentrated (altered) processing regime.

\section{Conclusions}

The TROFFEE 2004 airborne campaign in the Brazilian Amazon successfully obtained the first comprehensive emissions data for tropical deforestation fires. It was found that reactive OVOC accounted for about $80 \%$ of the NMOC emissions. We recommend emission factors for most of the major species produced by deforestation fires globally. Dry season haze layers in Brazil, due largely to biomass burning, extend to only about one-half the altitudes observed for dryseason smoke layers in Africa. This may have implications for global remote sensing of CO. Very large geographic areas were covered by the type of reactive smoke mixture that has proved hard to handle in photochemical models. Thus, the detailed effects this smoke had when it impacted areas $>1000 \mathrm{~km}$ to the south would be difficult to predict. Larger fires may emit more particles per unit mass of fuel burned and larger fires may be becoming more common in the Amazon basin (Sect. 2.3.2). Fire emission factors for acetonitrile differ substantially by ecosystem, but could be used with attention to fire type for source apportionment and with inverse modeling to estimate the amount of biomass burned.

The TROFFEE airborne campaign also completed an initial survey of the major fire theatres of the world using new technology and a consistent sampling strategy. The initial emissions from temperate and boreal forest fires and the chemical evolution of two plumes were sampled in 1997 and recommended EF were developed (Yokelson et al., 1999; Goode et al., 2000). In 2000, the chemical evolution of 4 dry plumes and one cloud-processed plume was measured (Yokelson et al., 2003a; Hobbs et al., 2003; Jost et al., 2003) as well as the initial emissions from the two largest types of global biomass burning; savanna fires (Yokelson et al., 2003a) and cooking fires (Bertschi et al., 2003a). In 2001 and 2003, PTR-MS was co-deployed with FTIR and whole air sampling on laboratory fires in savanna, Indonesian, boreal, tropical forest, and temperate fuels and recommended EF for an expanded suite of compounds were produced (Christian et al., 2003; 2004; 2007a ${ }^{1}$; Karl et al., 2007a).
We now know the top $\sim 20-50$ emissions from each main fire type and have quantified at best $\sim 70 \%$ of the NMOC. Of those NMOC, about 70-80\% are reactive OVOC and the NMHC are quickly converted to a series of short-lived OVOC intermediates. Rapid, very large changes in smoke composition, that are subgrid for global models, normally occur immediately after emission and there is no evidence for a fixed smoke age at which the chemical composition or rate of change is reproducible. For instance some plumes are characterized by high $\mathrm{OH}$ (Goode et al., 2000; Hobbs et al., 2003) and others by low OH (de Gouw et al., 2006). Detailed box models of the initial fast changes have relied on logical assumptions about unmeasured emissions; or proposed possible, but unconfirmed, heterogeneous processes to achieve partial agreement with observations (Tabazadeh et al., 2004; Trentmann et al., 2005).

More biomass burning research is needed including: (1) Airborne plume evolution studies, especially in smoky clouds, with enough instrumentation to constrain models and probe heterogeneous effects, (2) Development and/or deployment of instrumentation to quantify the unknown $30 \%$ of NMOC and species like HONO, which evidently strongly impact plume chemistry, (3) Development of well-validated high resolution, smoke chemistry models that can be confidently applied to different regional fire density and smoke transport scenarios and guide the parameterizations needed for global models, (4) Cooking fires are the second largest type of biomass burning, but a fairly large suite of emissions has only been measured on 4 of them: more cooking fires need to be sampled and more species need to be quantified such as acetonitrile and particles, (5) Better understanding of the environmental driving factors for RSC globally, (6) Better knowledge of the fuels that burn in southeast Asia, (7) Validation of space-based fire-related products such as hotspots, burned area, CO, aerosol loading, etc., and (8) Stronger integration of biomass burning measurements into campaigns focused on other issues.

Acknowledgements. The authors thank our pilots P. Celso and A. Pele. We also thank J. Carvalho, E. Alvarado, R. Gielow, and J. Carlos dos Santos for excellent logistical support and collaboration in Brazil. The planned fire and airborne research was supported largely by NSF grant ATM0228003. R. J. Yokelson was also supported by the Interagency Joint Fire Science Program, the Rocky Mountain Research Station, Forest Service, U.S. Department of Agriculture (agreements INT-97082-RJVA, RMRS-99508-RJVA, and 03-UV-1222049-046). The planned fire was also supported by Fundação de Amparo à Pesquisa do Estado de São Paulo - FAPESP, Brazil and the USDA Forest Service. The National Center for Atmospheric Research is sponsored by the National Science Foundation. This research benefited from the authors association with M. Keller, D. Wicklund, and the Large Scale Biosphere-Atmosphere Experiment in Amazônia (LBA). The authors gratefully acknowledge the NOAA Air Resources Laboratory for the provision of the HYSPLIT transport and dispersion model used in this publication at the READY website (http://www.arl.noaa.gov/ready.html). We thank D. Larko, 
R. McPeters, and the Ozone Processing Team at NASA's Goddard Space Flight Center for custom images of the TOMS earth probe AI for South America.

Edited by: J. Thornton

\section{References}

Andrade, S. M. A., Neto, W. N., and Miranda, H. S.: The dynamics of components of the fine fuel after recurrent prescribed fires in Central Brazil savannas, Proceedings of the Bushfire 99 Conference, Alburn, Australia, 1998.

Andreae, M. O., Anderson, B. E., Blake, D. R., Bradshaw, J. D., Collins, J. E., Gregory, G. L., Sachse, G. W., and Shipham, M. C.: Influence of plumes from biomass burning on atmospheric chemistry over the equatorial and tropical South Atlantic during CITE 3, J. Geophys. Res., 99, 12 793-12 808, doi:10.1029/94JD00263, 1994.

Andreae, M. O., Browell, E. V., Garstang, M., et al.: Biomassburning emissions and associated haze layers over Amazonia, J. Geophys. Res., 93, 1509-1527, doi:10.1029/88JD01585, 1988.

Andreae, M. O. and Merlet, P.: Emission of trace gases and aerosols from biomass burning, Global Biogeochem. Cycles, 15, 955966, doi:10.1029/2000GB001382, 2001.

Andreae, M. O., Rosenfeld, D., Artaxo, P., Costa, A. A., Frank, G. P., Longo, K. M., and Silva-Dias, M. A. F.: Smoking rain clouds over the Amazon, Science, 303, 1337-1342, 2004.

Babbitt, R. E., Ward, D. E., Susott, R. A., Artaxo, P., and Kaufmann, J. B.: A comparison of concurrent airborne and ground based emissions generated from biomass burning in the Amazon Basin, SCAR-B Proceedings, Transtec, São Paulo, Brazil, 1996.

Barbosa, R. I. and Fearnside, P. M.: Pasture burning in Amazonia: Dynamics of residual biomass and the storage and release of aboveground carbon, J. Geophys. Res., 101, 25 847-25857, doi:10.1029/96JD02090, 1996.

Bertschi, I. T., Yokelson, R. J., Ward, D. E., Christian, T. J., and Hao, W. M.: Trace gas emissions from the production and use of domestic biofuels in Zambia measured by open-path Fourier transform infrared spectroscopy, J. Geophys. Res., 108, 8469, doi:1029/2002/D002158, 2003a.

Bertschi, I. T., Yokelson, R. J., Ward, D. E., Babbitt, R. E., Susott, R. A., Goode, J. G., and Hao, W. M.: Trace gas and particle emissions from fires in large-diameter and belowground biomass fuels, J. Geophys. Res., 108, 8472, doi:10.1029/2002JD002100, 2003 b.

Blake, N. J., Blake, D. R., Sive, B. C., Chen, T. Y., Rowland, F. S., Collins, J. E., Sachse, G. W., and Anderson, B. E.: Biomass burning emissions and vertical distribution of atmospheric methyl halides and other reduced carbon gases in the South Atlantic region, J. Geophys. Res., 101, 24 151-24 164, 1996.

Brown, I. F., Schroeder, W., Setzer, A., de Los Rios Maldonado, M., Pantoja, N., Duarte, A., and Marengo, J.: Monitoring fires in southwestern Amazonia rain forests, EOS Trans. AGU, 87(26), 253-264, 2006.

Cardille, J. A. and Foley, J. A.: Agricultural land-use change in Brazilian Amazonia between 1980 and 1995: Evidence from integrated satellite and census data, Rem. Sens. Environ., 87, 551562, doi:10.1016/j.rse.2002.09.001, 2003.
Carvalho Jr., J. A., Costa, F. S., Veras, C. A. G., Sandberg, D. V., Alvarado, E. C., Gielow, R., Serra Jr., A. M., and Santos, J. C.: Biomass fire consumption and carbon release rates of rainforest-clearing experiments conducted in northern Mato Grosso, Brazil, J. Geophys. Res., 106, 17 877-17 887, doi:10.1029/2000JD900791, 2001.

Carvalho Jr., J. A., Higuchi, N., Araujo, T. M., and Santos, J. C.: Combustion completeness in a rainforest clearing experiment in Manaus, Brazil, J. Geophys. Res., 103, 13 195-13 199, doi:10.1029/98JD00172, 1998.

Chou, W. W., Wofsy, S. C., Harriss, R. C., Lin, J. C., Gerbig, C., and Sachse, G. W.: Net fluxes of $\mathrm{CO}_{2}$ in Amazonia derived from aircraft observations, J. Geophys. Res., 107, 4614, doi:10.1029/2001JD001295, 2002.

Christian, T., Kleiss, B., Yokelson, R. J., Holzinger, R., Crutzen, P. J., Hao, W. M., Saharjo, B. H., and Ward, D. E.: Comprehensive laboratory measurements of biomass-burning emissions: 1 . Emissions from Indonesian, African, and other fuels, J. Geophys Res., 108, 4719, doi:10.1029/2003JD003704, 2003.

Christian, T. J., Kleiss, B., Yokelson, R. J., Holzinger, R., Crutzen, P. J., Hao, W. M., Shirai, T., and Blake, D. R.: Comprehensive laboratory measurements of biomass-burning emissions: 2. First intercomparison of open-path FTIR, PTRMS, and GC-MS/FID/ECD, J. Geophys. Res., 109, D02311, doi:10.1029/2003JD003874, 2004.

Christian, T. J., Yokelson, R. J., Carvalho Jr., J. A., Griffith, D. W. T., Alvarado, E. C., Santos, J. C., Neto, T. G. S., Veras, C. A. G., and Hao, W. M.: The tropical forest and fire emissions experiment: Trace gases emitted by smoldering logs and dung on deforestation and pasture fires in Brazil, J. Geophys. Res., 112, D18308, doi:10.1029/2006JD008147, 2007b.

Cochrane, M. A., Alencar, A., Schulze, M. D., Souza Jr., C. M., Nepstad, D. C., Lefebvre, P., and Davidson, E. A.: Positive feedbacks in the fire dynamics of closed canopy tropical forests, Science, 284, 1832-1835, 1999.

Colman, J. J., Swanson, A. L., Meinardi, S., Sive, B. C., Blake, D. R., and Rowland, F. S.: Description of the analysis of a wide range of volatile organic compounds in whole air samples collected during PEM tropics A and B, Anal. Chem., 73, 37233731, 2001.

Coutinho, L. M.: Fire in the ecology of the Brazilian cerrado, in: Fire in the Tropical Biota: Ecosystem Processes and Global Challenges, edited by: Goldammer, J. G., p. 82-105, SpringerVerlag, Berlin, 1990.

Crutzen, P. J. and Andreae, M. O.: Biomass burning in the tropics: Impact on atmospheric chemistry and biogeochemical cycles, Science, 250, 1669-1677, 1990.

Crutzen, P. J., Delany, A. C., Greenberg, J., Haagenson, P., Heidt, L., Lueb, R., Pollock, W., Seiler, W., Wartburg, A., and Zimmerman, P.: Tropospheric chemical composition measurements in Brazil during the dry season, J. Geophys. Res., 2, 233-256, 1985.

de Gouw, J. A., Warneke, C., Stohl, A., et al.: Volatile organic compounds composition of merged and aged forest fire plumes from Alaska and western Canada, J. Geophys. Res., 111, D10303, doi:10.1029/2005JD006175, 2006.

Draxler, R. R. and Rolph, G. D.: HYSPLIT (HYbrid Single-Particle Lagrangian Integrated Trajectory) Model access via NOAA ARL READY Website (http://www.arl.noaa.gov/ready/hysplit4.html), 
NOAA Air Resources Laboratory, Silver Spring, MD, 2003.

Echalar, F., Artaxo, P., Martins, J. V., Yamasoe, M., Gerab, F., Maenhaut, W., and Holben, B.: Long-term monitoring of atmospheric aerosols in the Amazon Basin: Source identification and apportionment, J. Geophys. Res., 103, 31 849-31 864, 1998.

Emmons, L. K., Deeter, M. N., Gille, J. C., et al.: Validation of measurements of pollution in the troposphere (MOPITT) CO retrievals with aircraft in situ profiles, J. Geophys. Res., 109, D03309, doi:10.1029/2003JD004101, 2004.

Fearnside, P. M.: Fire in the tropical rain forest of the Amazon basin, in: Fire in the Tropical Biota: Ecosystem Processes and Global Challenges, edited by: Goldammer, J. G., p. 106-116, Springer Verlag, Berlin, 1990.

Fearnside, P. M.: Global warming and tropical land-use change: Greenhouse gas emissions from biomass burning, decomposition and soils in forest conversion, shifting cultivation and secondary vegetation, Climatic Change, 46, 115-158, doi:10.1023/A:1005569915357, 2000.

Fearnside, P. M., Leal Jr., N., and Fernandes, F. M.: Rainforest burning and the global budget: Biomass, combustion efficiency, and charcoal formation in the Brazilian Amazon, J. Atmos. Chem., 98, 733-743, 1993.

Ferek, R. J., Reid, J. S., Hobbs, P. V., Blake, D. R., and Liousse, C.: Emission factors of hydrocarbons, halocarbons, trace gases, and particles from biomass burning in Brazil, J. Geophys. Res., 103, 32 107-32 118, doi:10.1029/98JD00692, 1998.

Finlayson-Pitts, B. J. and Pitts Jr., J. N.: Atmospheric Chemistry: Fundamentals and Experimental Techniques, 1098 pp., John Wiley, Inc., New York, 1986.

Fishman, J., Fakhruzzaman, K., Cros, B., and Nganga, D.: Identification of widespread pollution in the southern hemisphere deduced from satellite analysis, Science, 252, 1693-1696, 1991.

Goode, J. G., Yokelson, R. J., Susott, R. A., and Ward, D. E.: Trace gas emissions from laboratory biomass fires measured by openpath FTIR: Fires in grass and surface fuels, J. Geophys. Res., 104, 21 237-21 245, doi:10.1029/1999JD900360, 1999.

Goode, J. G., Yokelson, R. J., Ward, D. E., Susott, R. A., Babbitt, R. E., Davies, M. A., and Hao, W. M.: Measurements of excess $\mathrm{O}_{3}, \mathrm{CO}_{2}, \mathrm{CO}, \mathrm{CH}_{4}, \mathrm{C}_{2} \mathrm{H}_{4}, \mathrm{C}_{2} \mathrm{H}_{2}, \mathrm{HCN}, \mathrm{NO}, \mathrm{NH}_{3}$, $\mathrm{HCOOH}, \mathrm{CH}_{3} \mathrm{COOH}, \mathrm{HCHO}$, and $\mathrm{CH}_{3} \mathrm{OH}$ in 1997 Alaskan biomass burning plumes by airborne Fourier transform infrared spectroscopy (AFTIR), J. Geophys. Res., 105, 22 147-22 166, doi:10.1029/2000JD900287, 2000.

Grainger, A.: The future environment for forest management in Latin America, in Management of the Forests of Tropical America: Prospects and Technologies, Institute of Tropical Forestry/USDA Forest Service, Washington, D.C., 1987.

Guenther, A., Hewitt, C. N., Erickson, D., et al.: A global model of natural volatile organic compound emissions, J. Geophys. Res., 100(D5), 8873-8892, 1995.

Guenther, A., Karl, T., Harley, P., Wiedinmyer, C., Palmer, P. I., and Geron, C.: Estimates of global terrestrial isoprene emissions using MEGAN (Model of Emissions of Gases and Aerosols from Nature), Atmos. Chem. Phys., 6, 3181-3210, 2006, http://www.atmos-chem-phys.net/6/3181/2006/.

Guild, L. S., Kaufmann, J. B., Ellingson, L. J., Cummings, D. L., Castro, E. A., Babbitt, R. E., and Ward, D. E.: Dynamics associated with total above ground biomass, C, nutrient pools, and biomass burning of primary forest and pasture in Rondônia,
Brazil during SCAR-B, J. Geophys. Res., 103, 32 091-32 100, doi:10.1029/98JD00523, 1998.

Hanst, P. L. and Hanst, S. T.: Gas measurement in the fundamental infrared region, in Air Monitoring by Spectroscopic Techniques, edited by M.W. Sigrist, p. 335-470, John Wiley, New York, 1994.

Hobbs, P. V., Reid, J. S., Kotchenruther, R. A., Ferek, R. J., and Weiss, R.: Direct radiative forcing by smoke from biomass burning, Science, 275, 1777-1778, 1997.

Hobbs, P. V., Sinha, P., Yokelson, R. J., Christian, T. J., Blake, D. R., Gao, S., Kirchstetter, T. W., Novakov, T., and Pilewskie, P.: Evolution of gases and particles from a savanna fire in South Africa, J. Geophys. Res., 108, 8485, doi:10.1029/2002JD002352, 2003.

Holben, B., Setzer, A., Eck, T. F., Pereira, A., and Slutsker, I.: Effect of dry-season biomass burning on Amazon basin aerosol concentrations and optical properties, 1992-1994, J. Geophys. Res., 101, 19465-19482, doi:10.1029/96JD01140, 1996.

Holzinger, R., Warneke, C., Hansel, A., Jordan, A., Lindinger, W., Scharffe, D. H., Schade, G., and Crutzen, P. J.: Biomass burning as a source of formaldehyde, acetaldehyde, methanol, acetone, acetonitrile, and hydrogen cyanide, Geophys. Res. Lett., 26, 1161-1164, doi:10.1029/1999GL900156, 1999.

Jost, C., Trentmann, J., Sprung, D., Andreae, M. O., McQuaid, J. B., and Barjat, H.: Trace gas chemistry in a young biomass burning plume over Namibia: Observations and model simulations, J. Geophys. Res., 108, 8482, doi:10.1029/2002JD002431, 2003.

Karl, T. G., Christian, T. J., Yokelson, R. J., Artaxo, P., Hao, W. M., and Guenther, A.: The tropical forest and fire emissions experiment: Method evaluation of volatile organic compound emissions measured by PTR-MS, FTIR, and GC from tropical biomass burning, Atmos. Chem. Phys. Discuss., 7, 8755-8793, 2007 ,

http://www.atmos-chem-phys-discuss.net/7/8755/2007/.

Karl, T. G., Guenther, A., Yokelson, R. J., Greenberg, J., Potosnak, M. J., Blake, D. R., and Artaxo P.: The tropical forest and fire emissions experiment: Emission, chemistry, and transport of biogenic volatile organic compounds in the lower atmosphere over Amazonia, J. Geophys. Res., 112, D18302, doi:10.1029/2007JD008539, 2007b.

Kauffman, J. B., Cummings, D. L., and Ward, D. E.: Relationships of fire, biomass and nutrient dynamics along a vegetation gradient in the Brazilian cerrado, J. Ecol., 82, 519-531, 1994.

Kauffman, J. B., Cummings, D. L., and Ward, D. E.: Fire in the Brazilian Amazon 2. Biomass, nutrient pools and losses in cattle pastures, Oecologia, 113, 415-427, doi:10.1007/s004420050394, 1998.

Kauffman, J. B., Sanford, R. L., Cummings, D. L., Salcedo, I. H., and Sampaio, E. V. S. B.: Biomass and nutrient dynamics associated with slash fires in neotropical dry forests, Ecology, 74, 140-151, 1993.

Kauffman, J. B. and Uhl, C.: Interactions of anthropogenic activities, fire, and rain forests in the Amazon basin, in: Fire in the Tropical Biota: Ecosystem Processes and Global Challenges, edited by: Goldammer, J. G., p. 117-134, Springer Verlag, Berlin, 1990.

Kaufman, Y. J. and Fraser, R. S.: The effect of smoke particles on clouds and climate forcing, Science, 277, 1636-1639, doi:10.1126/science.277.5332.1636, 1997.

Kaufman, Y. J., Setzer, A., Ward, D., Tanre, D., Holben, B. N., Men- 
zel, P., Pereira, M. C., and Rasmussen, R.: Biomass burning airborne and spaceborne experiment in the Amazonas (BASE-A), J. Geophys. Res., 97, 14 581-14 599, doi:10.1029/92JD00275, 1992.

Keene, W. C., Lobert, J. M., Crutzen, P. J., Maben, J. R., Scharffe, D. H., Landmann, T., Hély, C., and Brain, C.: Emissions of major gaseous and particulate species during experimental burns of southern African biomass, J. Geophys. Res., 111, D04301, doi:10.1029/2005JD006319, 2006.

Kreidenweis, S., Tyndall, G., Barth, M., Dentener, F., Lelieveld, J., and Mozurkewich, M.: Aerosols and clouds, in: Atmospheric Chemistry and Global Change, edited by: Brasseur, G. P., Orlando, J. J., and Tyndall, G. S., p. 117-155, Oxford University Press, New York, 1999.

Laurance, W. F.: Cut and run: The dramatic rise of transnational logging in the tropics, Trends Ecol. Evol., 15, 433-434, 1990.

Li, Q., Jacob, D. J., Bey, I., Yantosca, R. M., Zhao, Y., Kondo, Y., and Notholt, J.: Atmospheric hydrogen cyanide ( $\mathrm{HCN})$ : biomass burning source, ocean sink?, Geophys. Res. Lett., 27, 357-360, doi:10.1029/1999GL010935, 2000.

Lindinger, W., Jordan, A., and Hansel, A.: Proton-transfer-reaction mass spectrometry (PTR-MS): on-line monitoring of volatile organic compounds at pptv levels, Chem. Soc. Rev., 27, 347-375, doi:10.1039/a827347z, 1998.

Lobert, J. M., Scharffe, D. H., Hao, W. M., Kuhlbusch, T. A., Seuwen, R., Warneck, P., and Crutzen, P. J.: Experimental evaluation of biomass burning emissions: Nitrogen and carbon containing compounds, in: Global Biomass Burning: Atmospheric, Climatic, and Biospheric Implications, edited by: Levine, J. S., p. 289-304, MIT Press, Cambridge, 1991.

Mason, S. A., Field, R. J., Yokelson, R. J., Kochivar, M. A., Tinsley, M. R., Ward, D. E., and Hao, W. M.: Complex effects arising in smoke plume simulations due to inclusion of direct emissions of oxygenated organic species from biomass combustion, J. Geophys. Res., 106(D12), $12527-$ 12 540, doi:10.1029/2001JD900003, 2001.

Morton, D. C., DeFries, R. S., Shimabukuro, Y. E., Anderson, L. O., Arai, E., Espirito-Santo, F., Freitas, R., and Morisette, J.: Cropland expansion changes deforestation dynamics in the southern Brazilian Amazon, Proceedings of the National Academy of Sciences of the United States of America, 2006.

Ottmar, R. D.: Smoke source characteristics, in: Smoke Management Guide for Prescribed and Wildland Fire: 2001 Edition, edited by: Hardy, C., Ottmar, R., Peterson, J., Core, J., and Seamon, P., National Interagency Fire Center, Boise, ID, US, 2001.

Page, S. E., Siegert, F., Rieley, J. O., Boehm, H.-D. V., Jaya, A., and Limin, S.: The amount of carbon released from peat and forest fires in Indonesia during 1997, Nature, 420(6911), 61-65, 2002.

Pereira, E. B., Setzer, A. W., Gerab, F., Artaxo, P. E., Pereira, M. C., and Monroe, G.: Airborne measurements of aerosols from burning biomass in Brazil related to the TRACE A experiment, J. Geophys. Res., 101, 23 983-23 992, 1996.

Prather, M., Derwent, R., Ehhalt, D., Fraser, P., Sanhueza, E., and Zhou, X.: Other trace gases and atmospheric chemistry, in: Climate Change 1994: Radiative Forcing of Climate Change and an Evaluation of the IPCC IS92 Emission Scenarios, edited by: Houghton, J. T., Filho, L. G. M., Bruce, J., Lee, H., Callader, B. A., Haites, E., Harris, N., and Maskell, K., Cambridge University Press, New York, 1994.
Radke, L. F., Hegg, D. A., Hobbs, P. V., Nance, J. D., Lyons, J. H., Laursen, K. K., Weiss, R. E., Riggan, P. J., and Ward, D. E.: Particulate and trace gas emissions from large biomass fires in North America, in: Global Biomass Burning, edited by: J. Levine, p. 209-224, MIT Press, Cambridge, MA, 1991.

Reid, J. S., Hobbs, P. V., Ferek, R. J., Blake, D. R., Martins, J. V., Dunlap, M. R., and Liousse, C.: Physical, chemical, and optical properties of regional hazes dominated by smoke in Brazil, J. Geophys. Res., 103(D24), 32 059-32 080, doi:10.1029/98JD00458, 1998.

Schmid, B., Redemann, J., Russell, P. B., et al.: Coordinated airborne, spaceborne, and ground-based measurements of massive thick aerosol layers during the dry season in southern Africa, J. Geophys. Res., 108(D13), 8496, doi:10.1029/2002JD002297, 2003.

Shim, C., Wang, Y., Singh, H. B., Blake, D. R., and Guenther, A. B.: Source characteristics of oxygenated volatile organic compounds and hydrogen cyanide, J. Geophys. Res., 112, D10305, doi:10.1029/2006JD007543, 2007.

Singh, H. B., Kanakidou, M., Crutzen, P. J., and Jacob, D. J.: High concentrations and photochemical fate of oxygenated hydrocarbons in the global troposphere, Nature, 378(6552), 50-54, 1995.

Susott, R. A., Olbu, G. J., Baker, S. P., Ward, D. E., Kauffman, J. B., and Shea, R.: Carbon, hydrogen, nitrogen, and thermogravimetric analysis of tropical ecosystem biomass, in: Biomass Burning and Global Change, edited by: Levine, J. S., p. 350-360, MIT Press, Cambridge, 1996.

Tabazadeh, A., Yokelson, R. J., Singh, H. B., Hobbs, P. V., Crawford, J. H., and Iraci, L. T.: Heterogeneous chemistry involving methanol in tropospheric clouds, Geophys. Res. Lett., 31, L06114, doi:10.1029/2003GL018775, 2004.

Trentmann, J., Yokelson, R. J., Hobbs, P. V., Winterrath, T., Christian, T. J., Andreae, M. O., and Mason, S. A.: An analysis of the chemical processes in the smoke plume from a savanna fire, J. Geophys. Res., 110, D12301, doi:10.1029/2004JD005628, 2005.

Ward, D. E. and Radke, L. F.: Emissions measurements from vegetation fires: A comparative evaluation of methods and results, in: Fire in the Environment: The Ecological, Atmospheric and Climatic Importance of Vegetation Fires, edited by: Crutzen, P. J. and Goldammer, J. G., p. 53-76, John Wiley, New York, 1993.

Ward, D. E., Susott, R. A., Kauffman, J. B., Babbitt, R. E., Cummings, D. L., Dias, B., Holden, B. N., Kaufman, Y. J., Rasmussen, R. A., and Setzer, A. W.: Smoke and fire characteristics for Cerrado and deforestation burns in Brazil: BASE-B experiment, J. Geophys. Res., 97, 14601-14619, doi:10.1029/92JD01218, 1992.

Yokelson, R. J., Bertschi, I. T., Christian, T. J., Hobbs, P. V., Ward, D. E., and Hao, W. M.: Trace gas measurements in nascent, aged, and cloud-processed smoke from African savanna fires by airborne Fourier transform infrared spectroscopy (AFTIR), J. Geophys. Res., 108(D13), 8478, doi:10.1029/2002JD002322, 2003a.

Yokelson, R. J., Christian, T. J., Bertschi, I. T., and Hao, W. M.: Evaluation of adsorption effects on measurements of ammonia, acetic acid, and methanol, J. Geophys. Res., 108(D20), 4649, doi:10.1029/2003JD003549, 2003b.

Yokelson, R. J., Goode, J. G., Ward, D. E., Susott, R. A., Babbitt, R. E., Wade, D. D., Bertschi, I., Griffith, D. W. T., and Hao, W. M.: Emissions of formaldehyde, acetic acid, methanol, and other trace gases from biomass fires in North Carolina measured 
by airborne Fourier transform infrared spectroscopy, J. Geophys. Res., 104, 30 109-30 126, doi:10.1029/1999JD900817, 1999.

Yokelson, R. J., Susott, R., Ward, D. E., Reardon, J., and Griffith, D. W. T.: Emissions from smoldering combustion of biomass measured by open-path Fourier transform infrared spectroscopy, J. Geophys. Res., 102, 18 865-18 878, doi:10.1029/97JD00852, 1997.
Yokelson, R. J., Griffith, D. W. T., and Ward, D. E.: Openpath Fourier transform infrared studies of large-scale laboratory biomass fires, J. Geophys. Res., 101, 21 067-21 080, doi:10.1029/96JD01800, 1996. 